\title{
In Situ Neutral System Synthesis, Spectroscopic, and Biological Interpretations of Magnesium(II), Calcium(II), Chromium(III), Zinc(II), Copper(II) and Selenium(IV) Sitagliptin Complexes
}

\author{
Samy M. El-Megharbel ${ }^{1, *}$, Moamen S. Refat ${ }^{2}$ (D), Fawziah A. Al-Salmi ${ }^{3}$ and Reham Z. Hamza ${ }^{3, *}$ \\ 1 Department of Chemistry, College of Science, Zagazig University, Zagazig 44519, Egypt \\ 2 Department of Chemistry, College of Science, Taif University, P.O. Box 11099, Taif 21944, Saudi Arabia; \\ moamen@tu.edu.sa \\ 3 Department of Biology, College of Science, Taif University, P.O. Box 11099, Taif 21944, Saudi Arabia; \\ f.alsalmi@tu.edu.sa \\ * Correspondence: smelmegharbl@Zu.edu.eg (S.M.E.-M.); Reham.z@tu.edu.sa (R.Z.H.)
}

Citation: El-Megharbel, S.M.; Refat, M.S.; Al-Salmi, F.A.; Hamza, R.Z. In Situ Neutral System Synthesis, Spectroscopic, and Biological Interpretations of Magnesium(II),

Calcium(II), Chromium(III), Zinc(II), Copper(II) and Selenium(IV) Sitagliptin Complexes. Int. J. Environ. Res. Public Health 2021, 18, 8030. https://doi.org/10.3390/ ijerph18158030

Academic Editor: Paul B. Tchounwou

Received: 28 June 2021

Accepted: 21 July 2021

Published: 29 July 2021

Publisher's Note: MDPI stays neutral with regard to jurisdictional claims in published maps and institutional affiliations.

Copyright: (c) 2021 by the authors. Licensee MDPI, Basel, Switzerland. This article is an open access article distributed under the terms and conditions of the Creative Commons Attribution (CC BY) license (https:// creativecommons.org/licenses/by/ $4.0 /)$.
Abstract: Magnesium(II), calcium(II), chromium(III), zinc(II), copper(II), and selenium(IV) sitagliptin (STG) complexes-with the general formulas $\left[\mathrm{Mg}(\mathrm{STG})_{2}(\mathrm{Cl})_{2}\right] \cdot 6 \mathrm{H}_{2} \mathrm{O},\left[\mathrm{Ca}(\mathrm{STG})_{2}(\mathrm{Cl})_{2}\right],\left[\mathrm{Cr}(\mathrm{STG})_{2}(\mathrm{Cl})_{2}\right]$ $\mathrm{Cl} \cdot 6 \mathrm{H}_{2} \mathrm{O},\left[\mathrm{Zn}(\mathrm{STG})_{2}(\mathrm{Cl})_{2}\right],\left[\mathrm{Cu}(\mathrm{STG})_{2}(\mathrm{Cl})_{2}\right] \cdot 2 \mathrm{H}_{2} \mathrm{O}$, and $\left[\mathrm{Se}(\mathrm{STG})_{2}(\mathrm{Cl})_{2}\right] \mathrm{Cl}_{2}$, respectively-were designed and synthesized by the chemical reactions between metal(II, III, and IV) chloride salts with an STG ligand in situ methanol solvent in a 1:2 stoichiometric ratio (metal:ligand). Tentative structures of the complexes were proposed based on elemental analysis, molar conductance, magnetic moments, thermogravimetric analysis, and spectral (infrared, electronic, and ${ }^{1} \mathrm{H}$ NMR) data. The particle size and morphological investigation were checked on the bases of scanning electron microscopy, transmission electron microscopy, and X-ray powder diffraction analyses. All the $\mathrm{Mg}^{2+}, \mathrm{Ca}^{2+}, \mathrm{Cr}^{3+}, \mathrm{Zn}^{2+}$, $\mathrm{Cu}^{2+}$, and $\mathrm{Se}^{4+}$ complexes were found to be six-coordinated, wherein the STG ligands act as bidentate chelating agents. This study demonstrates that pancreatic tissues are affected by the induction of experimental diabetes mellitus and clarifies the potential of the synthesized STG complexes, which was found to more significantly improve insulin secretion and the pancreatic and glycometabolic complications of diabetic rats than STG alone.

Keywords: sitagliptin; complexes; spectroscopic; morphology; STZ; diabetes

\section{Introduction}

Metal ions play important roles in our life processes. It is well known that that both cellular and semi-cellular functions involve metals. The vital role of inorganic salts in living systems can be revealed by studying biological and biochemical systems. The chemistry of inorganic compounds is not the "dead chemistry" that lot of people may imagine [1-3]. Presently, metal ions are as important components of life as organic compounds. For example, in cells, $\mathrm{Mg}^{+2}$ and $\mathrm{Ca}^{+2}$ ions play regulatory important roles. In living systems, metallothionine proteins are rich in mineral ions. Cytotoxicity and antagonizing Cdinduced carcinogenesis can be inhibited in vivo using divalent cations of zinc, calcium, and magnesium. The formation of protein complexes involves the transportation of Fe and other metals by blood plasma [1]. $\mathrm{Cu}$ is mainly known as a metallic element that is primarily associated with $\mathrm{Cu}$-dependent cellular enzymes. For many diseases, minerals are also used as inorganic medicines. However, the focus in this article is on of metal molecule interactions, as well as the chemistry and structure of metal complexes [1-10].

Naturally occurring mineral compounds are vital for life [11]. Human bones require calcium. Cellular activities depend on magnesium. Additionally, potassium and magnesium are the most abundant minerals in every cell. Divalent calcium and magnesium, as well as zinc, copper, iron, and manganese, participate in the biological processes of 
the nucleus, are present in detectable quantities, and are associated with DNA and RNA in the cellular system [12]. The active formation of RNA depends on the concentration of $\mathrm{Mg}^{2+}$ or $\mathrm{Mn}^{2+}$. Enzymes in both plants and animals depend on energy provided by magnesium. Magnesium is known to provide energy by stimulating the production of adenosine triphosphate (ATP), which provides energy to billions of cells in our bodies. Mg is the catalyst or stimulant for this reaction and countless other physical activities.

Sitagliptin (STG) is the first agent from gliptins that has been used in the USA since 2006 and in Europe since 2009. Gliptins are drugs for the treatment of diabetes mellitus (type II) by inhibiting DPP4, the enzyme that inactivates glucose-dependent insulinotropic polypeptide (GIP). GIP serves as important stimulator of insulin secretion and a regulator of blood glucose concentration. Furthermore, STG is known to possess antioxidant and anti-inflammatory properties [13,14]. Thus, the inhibition of DPP4 leads to decreases of blood glucose levels in diabetic patients [15]. STG, which is a DPP-4i, has been shown to manage apoptosis and oxidative stress in type I diabetics and animal models [16]. The daily treatment of type II diabetes patients with STG has revealed a suitable glycemic control, as well as a significant reduction in glycosylated hemoglobin (HbA1c), with almost no hypoglycemic risk [17]. Researchers evaluated the pancreatic tissues' safety in the Trials Evaluating Cardiovascular Outcomes with STG (TECOS). They demonstrated a small risk for incidence of pancreatitis with STG therapy. Additionally, the registration of some cases with associated acute pancreatitis pushed the FDA to announce a post-marketing safety warning to STG [18].

Current developments in the design of metal-based therapeutic agents have demonstrated increasingly important research attempts to develop new compounds with fewer toxic side effects [4-8]. The present article aimed to study the chemical structures of STG complexes with $\mathrm{Mg}^{2+}, \mathrm{Ca}^{2+}, \mathrm{Cr}^{3+}, \mathrm{Zn}^{2+}, \mathrm{Cu}^{2+}$, and $\mathrm{Se}^{4+}$ using $\mathrm{CHN}$ elemental, molar conductance, FT-IR, magnetic susceptibility, electronic UV-Vis, ${ }^{1} \mathrm{H}$ NMR, thermogravimetric analysis (TGA/DrTGA), XRD, SEM, and TEM analyses. Additionally, this study was designed to evaluate the effect of STG and STG-metal complexes on oxidative damage induced by STZ in decreasing blood glucose levels.

\section{Experimental}

\subsection{Chemical Experiments}

Commercially available chemicals were purchased from commercial suppliers (SigmaAldrich Chemical Company (St. Louis, MO, USA)) and used as received, used without further purification. Additionally, $407.31 \mathrm{~g} / \mathrm{mol}$ of STG (CAS number: 486460-32-6; $\mathrm{C}_{16} \mathrm{H}_{15} \mathrm{~F}_{6} \mathrm{~N}_{5} \mathrm{O}$ ) with a purity of $\geq 98 \%$ were used.

Each STG ligand (2 mmol) and divalent $\mathrm{Mg}^{2+}, \mathrm{Ca}^{2+}, \mathrm{Cr}^{3+}, \mathrm{Zn}^{2+}, \mathrm{Cu}^{2+}$, and $\mathrm{Se}^{4+}$ $(1 \mathrm{mmol})$ were mixed in $50 \mathrm{~mL} \mathrm{CH} 3 \mathrm{OH}$ and refluxed for $2 \mathrm{~h}$. The produced white $\left(\mathrm{Mg}^{2+}\right.$, $\mathrm{Ca}^{2+}, \mathrm{Zn}^{2+}$, and $\left.\mathrm{Se}^{4+}\right)$, green $\left(\mathrm{Cr}^{3+}\right)$, and blue $\mathrm{Cu}^{2+}$ solutions were evaporated to half their original volume and allowed to precipitate. Filtration, washing with methanol, and drying in a vacuum desiccator over anhydrous $\mathrm{CaCl}_{2}$ were carried out for the synthesized complexes.

The $\mathrm{C}, \mathrm{H}$, and $\mathrm{N}$ percentage determined using Vario EL Fab. The metal content and water percentage were gravimetrically determined. FT-IR spectral data for the synthesized complexes were measured using an infrared Bruker spectrophotometer ranged between 400 and $4000 \mathrm{~cm}^{-1}$. Magnetic susceptibility measurements were performed with a SHERWOOD SCIENTIFIC (Cherry Hinton Rd., Cambridge, UK) magnetic susceptibility balance. Conductance was measured with a HACH conductivity meter model in a dimethyl sulfoxide solvent at a concentration of $10^{-3} \mathrm{M}$ for synthesized complexes. ${ }^{1} \mathrm{H}$ NMR was recorded as dimethyl sulfoxide solutions on a Bruker $600 \mathrm{MHz}$ spectrometer using tetramethyl silane as the internal standard. The electronic absorption spectra were recorded in DMSO solvent within a range of 900-200 nm using a UV2 Unicam UV/Vis spectrophotometer fitted with a quartz cell of a $1.0 \mathrm{~cm}$ path length. The X-ray diffraction patterns were recorded with an X'Pert PANanalytical PRO, which targeted copper with a secondary monochromate. The surface morphologies for the particles of complexes were 
visualized using Quanta FEG 250 scanning (SEM) (JEOL, Akishima, Tokyo, Japan) and transmission (TEM) electron microscopes generating a $20 \mathrm{kV}$ accelerating voltage, and the shapes and sizes of these particles were visualized using JEOL JEM-1200 EX II and JEOL 100s microscopy, respectively. The thermogravimetric analysis of the complexes was performed from room temperature to $800{ }^{\circ} \mathrm{C}$ using a TGA/DTA-50H Shimadzu thermal analyzer (JEOL, Akishima, Tokyo, Japan).

\subsection{Biological Experiments}

\subsubsection{Experimental Animals}

Ninety male albino rats (10 rat/each group) weighing about 170-200 g and aged 3 months were kept in clean metal cages while ensuring good ventilation. Male rats were provided healthy diets. All efforts were made to reduce animal suffering during the experimental work. The experimental design was approved by the Taif University Ethical Committee (approval number: 42-0074) and followed international guidelines for animal use and care.

\subsubsection{Drugs and Chemicals}

A $1 \mathrm{~g}$ vial of streptozotocin (STZ) was obtained from Sigma-Aldrich Company. STG was obtained in the form of JANUVIA ${ }^{\circledR}$ tablets (Merck Sharp and Dohme Ltd., Pavia, Italy). Each tablet was ground and then dissolved in $0.5 \%$ carboxymethyl cellulose to get a suspension form.

\subsubsection{Experimental Induction of Diabetes Mellitus}

After the period of adaptation, an STZ solution was freshly prepared and administered to fasted animals via intraperitoneal (i.p) injection directly after preparation $\left(50 \mathrm{mg} \cdot \mathrm{kg}^{-1}\right)$ [19], accompanied by a fat-fed diet to induce type II diabetes mellitus according to [20]. The experimental diabetic animals were fed with a high-fat diet for 3 weeks and then i.p. injected with STZ. The diet of experimental animals consisted of $60 \%$ fat, $20 \%$ carbohydrates, and $20 \%$ protein. After the end of this period, the rats fasted for $8 \mathrm{hr}$ and then received a single i.p. injection of STZ $(50 \mathrm{mg} / \mathrm{kg})$ that was freshly prepared in citrate buffer $(\mathrm{Ph}=4.5)$. At $72 \mathrm{~h}$ after STZ i.p. injection, the fasting blood glucose level of each rat was recorded by using an Accu-Chek glucometer (Roche, Germany). The diabetic rats with blood glucose levels greater that $280 \mathrm{mg} / \mathrm{dL}$ were selected as diabetics, and then we made another glucometer estimation after 3 days to ensure hyperglycemia. The treatments were started after diabetes induction and continued daily for 30 consecutive days.

Male albino rats were randomly divided into 9 groups. Group I (control group) was treated with normal physiological saline, group II (STZ group) received a "single dose" of STZ (50 mg.kg ${ }^{-1}$ ) (i.p.) [1], group III STZ rats were orally treated with STG $\left(10 \mathrm{mg} \cdot \mathrm{kg}^{-1}\right)$ [21], group IV (diabetic rats) received a single oral dose of $\mathrm{Mg} / \mathrm{STG}$ $\left(10 \mathrm{mg} \cdot \mathrm{kg}^{-1}\right)$, and groups V, VI, VI, and VII were exposed to STZ (diabetic rats) and then orally treated with $\mathrm{Cu} / \mathrm{STG}, \mathrm{Zn} / \mathrm{STG}, \mathrm{Ca} / \mathrm{STG}, \mathrm{Cr} / \mathrm{STG}$, and Se/STG at the previously described same dose.

\subsubsection{Blood Samples Collection}

With light anesthesia, blood samples from the eye plexus were collected in capillary tubes. The blood samples were centrifuged at 6000 r.p.m for $15 \mathrm{~min}$ to perform the biochemical analyses.

\subsubsection{Serum Blood Glucose, C-peptide, Insulin, and $\mathrm{HbA1c}$}

Blood glucose levels were evaluated with Biodiagnostic commercial kits, and fasting serum insulin levels were evaluated with a rat ELISA kit (ALPCO Diagnostics, Salem, NH, USA). C-peptide (Sigma-Aldrich) and HbA1c (Cusabio Co., Wuhan, China) levels were measured with ELISA kits. 


\subsubsection{Preparation of Pancreatic Tissue Homogenates}

Male rats were ethically decapitated, and their pancreatic tissues were stored for further investigation. A small portion of the pancreatic tissues was used to estimate the antioxidant biomarkers. Pancreatic tissues were homogenized in a cold buffer and centrifuged at 5000 r.p.m for about $2 \mathrm{~h}$. The obtained supernatant was stored at $-80^{\circ} \mathrm{C}$.

\subsubsection{Determination of Oxidative Stress Markers}

The pancreatic tissue homogenates were used to estimate the GRx "reduced glutathione" level, following the work of Sedlak and Lindsay [22]. Malondialdehyde (MDA) content was determined using the method of Ohkawa et al. [23]. The catalase (CAT) level was determined using the method of Beers and Sizer [24].

\subsubsection{Histological Analysis of Pancreas Tissues}

Pancreatic tissues were fixed in about $10 \%$ formalin "neutral-buffered". Following the fixation, the pancreatic tissue samples were processed and then stained with hematoxylin and eosin for examination under a light microscope.

\subsubsection{Statistical Analysis}

The collected data were entered into and analyzed by computer using Statistical Package of Social Services, version 27 (SPSS) (IBM, Armonk, NY, USA, 2020). KruskalWallis and Dunn's multiple comparison tests were used. In all the tests, a $p$ value of $<0.05$ was taken as significant.

\section{Results and Discussion}

\subsection{Chemistry Part}

\subsubsection{Microanalytical and Molar Conductance Data}

These compounds have a high stability at room temperature, low solubility in polar and nonpolar solvents, and a high solubility in DMF and DMSO under gently heating. The conductivity measurements of the magnesium(II), calcium(II), chromium(III), zinc(II), copper(II), and selenium(IV) STG complexes were 25, 32, 76, 29, 33, and $89 \mu \mathrm{s} / \mathrm{cm}$, respectively. Electrolytic measurements of the trivalent chromium and Se(IV) complexes revealed that their 1:1 electrolytic nature, which suggests that one or two $\mathrm{Cl}^{-}$anions exist outside the coordination sphere [25]. The dissolution of these two synthesized STG complexes gave a white precipitate when mixed with an $\mathrm{AgNO}_{3}$ reagent, which confirmed the existence of a $\mathrm{Cl}^{-}$ion in the outer coordination sphere. However, the conductivity measurements of magnesium(II), calcium(II), zinc(II), and copper(II) STG complexes lie in the range of $25-33 \mu \mathrm{s} \mathrm{cm}^{-1}$ at $25^{\circ} \mathrm{C}$. This low conductivity measurement values of the $10^{-3} \mathrm{M}$ concentrated solutions in DMSO showed them to be non-electrolytes. The elemental analysis (Table 1) revealed that the STG complexes have 1:2 metal-to-ligand ratios, as shown in Figure 1.

Table 1. Analytical data of the STG complexes.

\begin{tabular}{|c|c|c|c|c|c|}
\hline \multirow{2}{*}{ Complexes } & \multirow{2}{*}{ Molecular Weight } & \multicolumn{4}{|c|}{ Elemental Analysis \% Found (Calcd.) } \\
\hline & & $\mathrm{C}$ & $\mathbf{H}$ & $\mathbf{N}$ & $\mathbf{M}$ \\
\hline$\left[\mathrm{Mg}(\mathrm{STG})_{2}(\mathrm{Cl})_{2}\right] \cdot 6 \mathrm{H}_{2} \mathrm{O}$ & 1017.94 & $37.46(37.76)$ & $4.11(4.16)$ & $13.29(13.76)$ & $2.30(2.39)$ \\
\hline$\left[\mathrm{Ca}(\mathrm{STG})_{2}(\mathrm{Cl})_{2}\right]$ & 925.62 & $41.50(41.52)$ & $3.20(3.27)$ & $15.10(15.13)$ & $4.21(4.33)$ \\
\hline$\left[\mathrm{Cr}(\mathrm{STG})_{2}(\mathrm{Cl})_{2}\right] \mathrm{Cl} \cdot 6 \mathrm{H}_{2} \mathrm{O}$ & 1081.08 & $35.48(35.55)$ & $3.90(3.92)$ & $12.93(12.96)$ & $4.80(4.81)$ \\
\hline$\left[\mathrm{Zn}(\mathrm{STG})_{2}(\mathrm{Cl})_{2}\right]$ & 950.92 & $40.39(40.42)$ & $3.08(3.18)$ & $14.66(14.73)$ & $6.83(6.88)$ \\
\hline$\left[\mathrm{Cu}(\mathrm{STG})_{2}(\mathrm{Cl})_{2}\right]_{2} \cdot \mathrm{H}_{2} \mathrm{O}$ & 985.12 & $39.00(39.02)$ & $3.44(3.48)$ & $14.20(14.22)$ & $6.42(6.45)$ \\
\hline$\left[\mathrm{Se}(\mathrm{STG})_{2}(\mathrm{Cl})_{2}\right] \mathrm{Cl}_{2}$ & 1035.41 & $37.09(37.12)$ & $2.90(2.92)$ & $13.50(13.53)$ & $7.61(7.63)$ \\
\hline
\end{tabular}


<smiles>N[C@@H](CC(=O)N1CCn2c(nnc2C(F)(F)F)C1)Cc1cc(F)c(F)cc1F</smiles><smiles>N[C@@H](CC(=O)N1CCn2c(nnc2C(F)(F)F)C1)Cc1cc(F)c(F)cc1F</smiles>

$\mathrm{CuCl}_{2} \cdot 2 \mathrm{H}_{2} \mathrm{O}$

$\mathrm{CrCl}_{3} \cdot 6 \mathrm{H}_{2} \mathrm{O}$ $\mathrm{MgCl}_{2} \cdot 6 \mathrm{H}_{2} \mathrm{O}$

$\mathrm{ZnCl}_{2}$

$\mathrm{CaCl}_{2}$

$\mathrm{SeCl}_{4}$

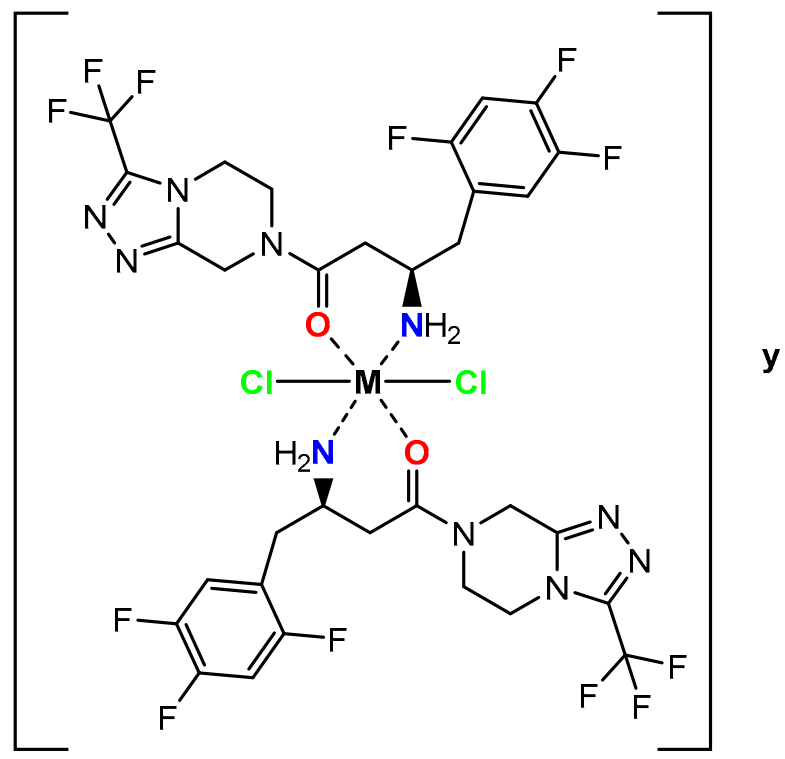

$$
\begin{aligned}
& M=\mathrm{Mg}(\mathrm{II}), \mathrm{Ca}(\mathrm{II}), \mathrm{Cr}(\mathrm{III}), \mathrm{Zn}(\mathrm{II}), \mathrm{Cu}(\mathrm{II}) \& \mathrm{Se}(\mathrm{IV}) \\
& y=6 \mathrm{H}_{2} \mathrm{O}\left(\mathrm{Mg}^{2+}\right), \mathrm{Cl}_{6} 6 \mathrm{H}_{2} \mathrm{O}\left(\mathrm{Cr}^{3+}\right), 2 \mathrm{H}_{2} \mathrm{O}\left(\mathrm{Cu}^{2+}\right) \& \mathrm{Cl}_{2}\left(\mathrm{Se}^{4+}\right) ;
\end{aligned}
$$

Figure 1. Suggested structures of STG complexes.

\subsubsection{Electronic Spectra and Magnetic Measurements}

The electronic spectra of the copper (II) STG ([Cu(STG $\left.\left.)_{2}(\mathrm{Cl})_{2}\right] \cdot 2 \mathrm{H}_{2} \mathrm{O}\right)$ complex displayed three bands at 12,048, 16,529, and 20,202 $\mathrm{cm}^{-1}$ due to ${ }^{2} \mathrm{~B}_{1 \mathrm{~g}} \rightarrow{ }^{2} \mathrm{~B}_{2 \mathrm{~g}},{ }^{2} \mathrm{~B}_{1 \mathrm{~g}} \rightarrow{ }^{2} \mathrm{~A}_{2 \mathrm{~g}}$, and ${ }^{2} \mathrm{~B}_{1 \mathrm{~g}} \rightarrow{ }^{2} \mathrm{E}_{1 \mathrm{~g}}$ transitions, respectively, which supported the idea that the $\mathrm{Cu}$ (II) complex has a distorted octahedral geometry [26,27]. The magnetic moment of this complex was found to be $1.81 \mathrm{BM}$, which confirmed its octahedral geometry. The assignment of various $\mathrm{d}-\mathrm{d}$ transitions and charge transfer bands in the spectrum of the $\left[\mathrm{Cr}(\mathrm{STG})_{2}(\mathrm{Cl})_{2}\right] \mathrm{Cl}^{-} \cdot 6 \mathrm{H}_{2} \mathrm{O}$ complex was performed based on the work of Lever [26] and Lever and Mantovani [27]. For the $\mathrm{Cr}(\mathrm{III})$ complex, the electronic spectrum was recorded in DMSO at room temperature. The electronic spectrum of the trivalent chromium complex have three bands at $19231(v 1), 25974(v 2)$, and $41667 \mathrm{~cm}^{-1}(v 3)$ corresponding to ${ }^{4} \mathrm{~A}_{2 \mathrm{~g}} \rightarrow{ }^{4} \mathrm{~T}_{2 \mathrm{~g}}(\mathrm{~F}),{ }^{4} \mathrm{~A}_{2 \mathrm{~g}} \rightarrow{ }^{4} \mathrm{~T}_{1 \mathrm{~g}}(\mathrm{~F})$, and ${ }^{4} \mathrm{~A}_{2 \mathrm{~g}} \rightarrow{ }^{4} \mathrm{~T}_{1 \mathrm{~g}}(\mathrm{P})$ transitions, respectively-all of which are characteristics of an octahedral geometry around the $\mathrm{Cr}$ (III) ion [28]. The magnetic moment value obtained for the $\mathrm{Cr}(\mathrm{III})$ complex was $3.88 \mathrm{BM}$, which corresponds to an octahedral field. In the case of the STG complexes of $\mathrm{Mg}(\mathrm{II}), \mathrm{Ca}(\mathrm{II}), \mathrm{Zn}(\mathrm{II})$, and $\mathrm{Se}(\mathrm{IV})$, no significant absorption bands in their electronic spectra were obtained due to the diamagnetic nature of these metal ions. The electronic spectra of the divalent magnesium, calcium, zinc, and Se(IV) complexes showed a range of absorption bands at $240-265 \mathrm{~nm}$; these bands can be attributed to the $M \rightarrow L$ charge transfer transition.

\subsubsection{Infrared Spectra}

The FT-IR spectrum of sitagliptin (Figure 2A and Table 2) showed a number of distinguish bands, such as a strong broad band at $3357 \mathrm{~cm}^{-1}$ that can be assigned to the $\mathrm{N}-\mathrm{H}$ stretching vibration of the $\mathrm{NH}_{2}$ group [29-31], weak and medium strong bands at 3059, 2917 and $2850 \mathrm{~cm}^{-1}$ that can be assigned to the $\mathrm{C}-\mathrm{H}$ vibration stretching of the aromatic and aliphatic groups, and medium-to-strong bands at 1669 and $1634 \mathrm{~cm}^{-1}$ that can be attributed to the $v(\mathrm{C}=\mathrm{O})$ and $v(\mathrm{C}=\mathrm{O})$ vibration stretching of the carbonyl group and 1,2,4triazole ring, respectively. The strong band at $1609 \mathrm{~cm}^{-1}$ can be attributed to $\mathrm{N}-\mathrm{H}$ bending motion. The three bands at 1556, 1514, and $1426 \mathrm{~cm}^{-1}$ can be assigned to the $v(\mathrm{C}-\mathrm{N})$ and $v(\mathrm{C}-\mathrm{N})$ stretching vibrations. The vibrations at 1324 and $1274 \mathrm{~cm}^{-1}$ can be attributed to 
$\mathrm{CH}$ in plane bending, whereas the bands at 1146 and $978 \mathrm{~cm}^{-1}$ can be attributed to the stretching vibration of the $v(\mathrm{C}-\mathrm{F})$ bond $[30,31]$. In addition, the characteristic bands at 913 , 881,844 , and $725 \mathrm{~cm}^{-1}$ can be attributed to the $\mathrm{CH}$ out-of-plane bending [29]. The $-\mathrm{NH}_{2}$ group stretching vibration was found to be displaced to lower frequency values at 3300, $3316,3340,3341,3305$, and $3340 \mathrm{~cm}^{-1}$ for the $\mathrm{Mg}^{2+}, \mathrm{Ca}^{2+}, \mathrm{Cr}^{3+}, \mathrm{Zn}^{2+}, \mathrm{Cu}^{2+}$, and $\mathrm{Se}^{4+}$ STG complexes, respectively, after chelation. In the FT-IR spectra of the metal complexes, the bands due to the bending vibration of $-\mathrm{NH}_{2}$ group disappeared, which indicated the chelation of the STG ligand with the metal ion via an $\mathrm{N}$ atom of the $\mathrm{NH}_{2}$ group. The vibration stretching of the $(\mathrm{C}=\mathrm{O})$ group in the case of the free STG ligand was shown at $1669 \mathrm{~cm}^{-1}$ and disappeared in the spectra of STG complexes, which indicated the involvement of the oxygen atom of the $\mathrm{C}=\mathrm{O}$ group in chelation with metal ions. The band at $1634 \mathrm{~cm}^{-1}$ for the STG ligand refers to the stretching vibration of $\mathrm{C}=\mathrm{N}$ for the 1,2,4-triazole ring, which remained unshifted or slightly shifted to higher wavenumbers in STG complexes, so the nitrogen atom of the $\mathrm{C}=\mathrm{N}$ group does not participate in the coordination process. The free STG has two stretching bands, at 1146 and $978 \mathrm{~cm}^{-1}$ in the C-F region. After complexation, the maxima were found to be the same, suggesting that the $\mathrm{C}-\mathrm{F}$ bond is far from the place of complexity. The presence of medium-to-weak bands at $558-445 \mathrm{~cm}^{-1}$ can be attributed to metal-oxygen and metal-nitrogen stretching vibration motions [29]. Therefore, our infrared spectral results showed that the respective metal ions coordinate with the STG ligand through amino and carbonyl groups and STG acts as a bidentate chelate, as shown in Figure 2B-G.

\subsection{4. ${ }^{1} \mathrm{H}-\mathrm{NMR}$ Spectra}

The ${ }^{1} \mathrm{H}$-NMR spectrum of the STG ligand showed two signals in the regions of $\delta$ 7.538-7.470 and $\delta 4.089-4.848 \mathrm{ppm}$, as well as three signals at $\delta 2.694-3.981 \mathrm{ppm}$ due to trifluorophenyl ring protons, pyrazine ring protons, and $\mathrm{CH}_{2}$ and $\mathrm{CH}$ of butan-1-one proton, respectively. The ${ }^{1} \mathrm{H}-\mathrm{NMR}$ spectrum of the magnesium(II) complex showed signals in the region of $\delta 8.221-6.670 \mathrm{ppm}$, which may have been due to four different types of trifluorophenyl ring protons. The signals caused by the pyrazine ring and butan-1-one moiety protons shifted to downfield in the range of $\delta 4.960-4.259$ and $\delta 4.134-2.803 \mathrm{ppm}$, respectively, which was due to the decreased electron density and deshielding of protons caused by the participation of the $\mathrm{NH}_{2}$ and $\mathrm{CO}$ groups in coordination.

A

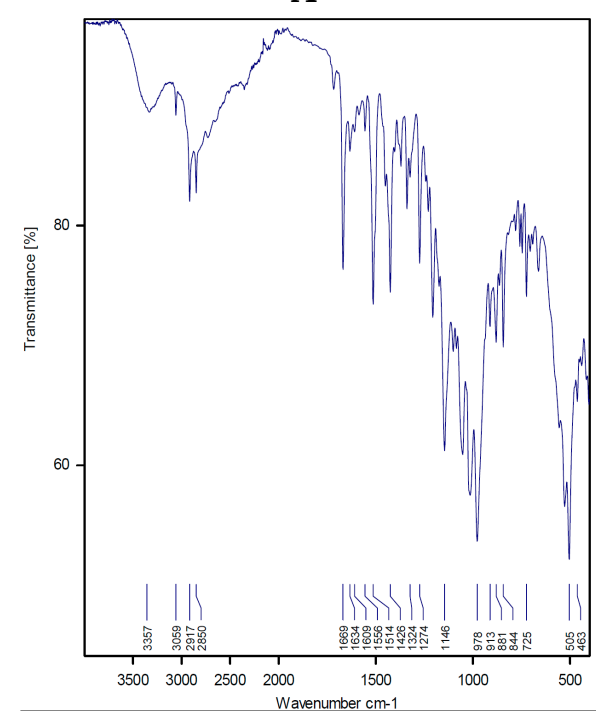

B

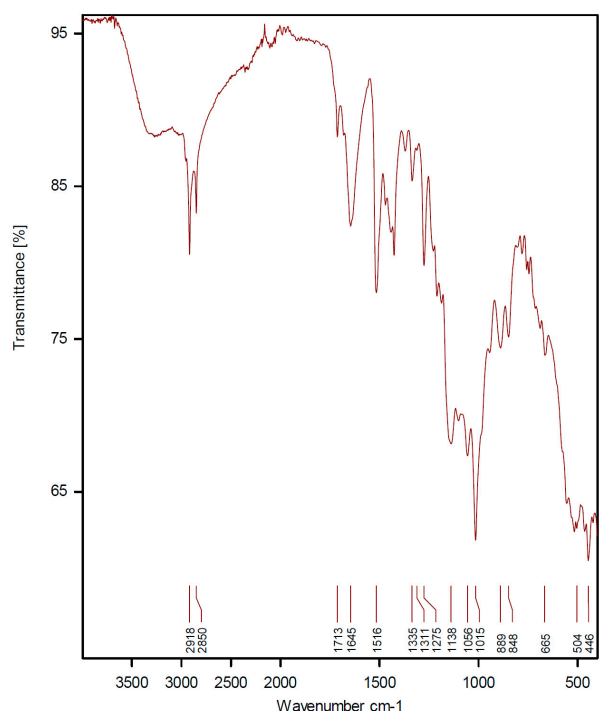

Figure 2. Cont. 

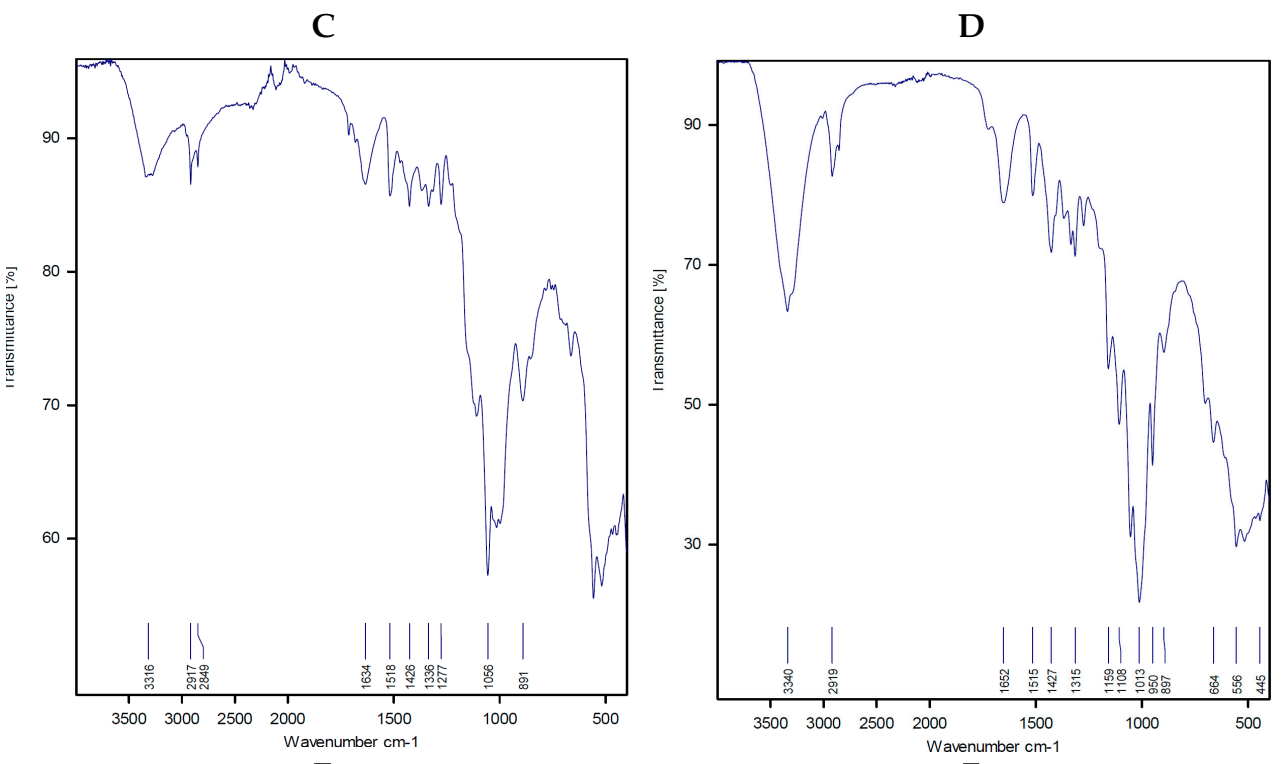

E
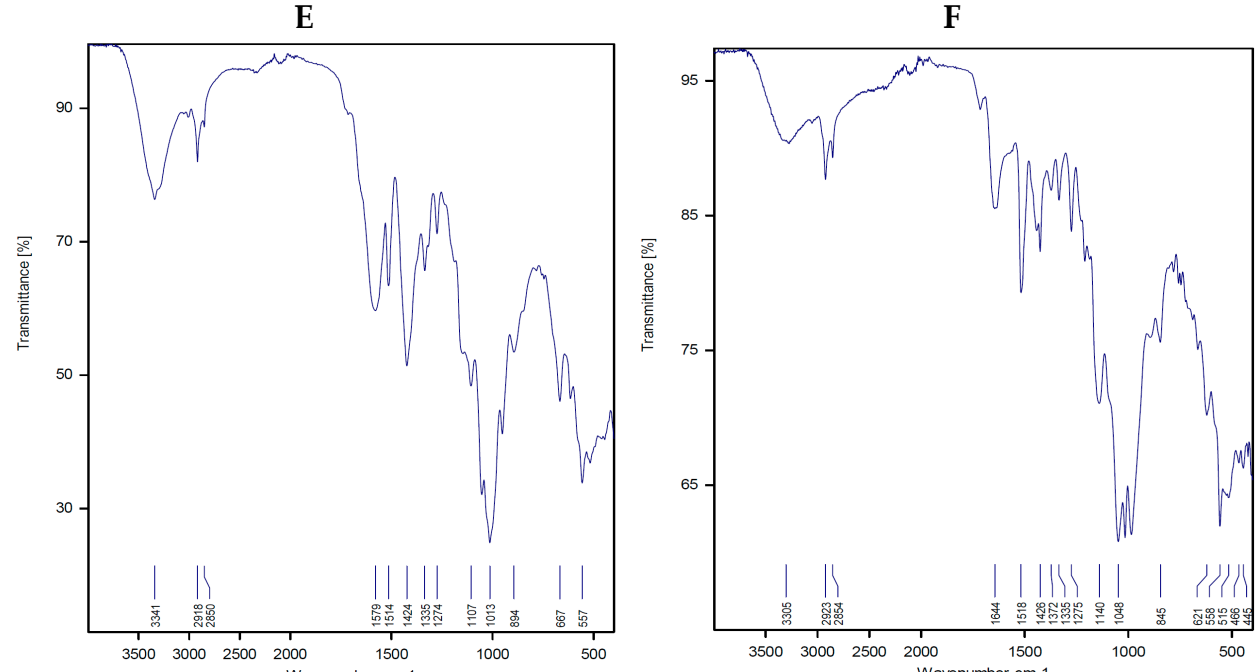

G

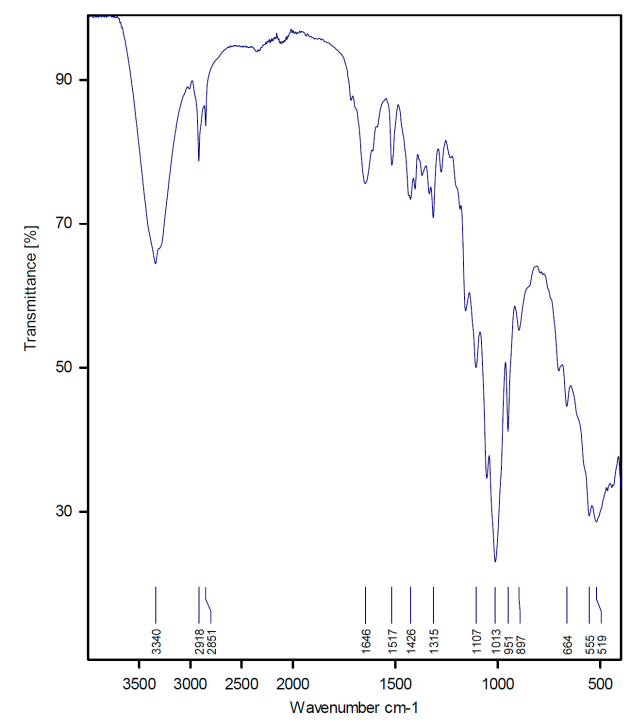

Figure 2. Infrared spectra of the (A) STG, (B) $\mathrm{Mg}$ (II), (C) Ca(II), (D) $\mathrm{Cr}$ (III), (E) $\mathrm{Zn}$ (II), (F) Cu(II), and (G) Se(IV) complexes. 
Table 2. Infrared spectral bands and assignments of STG and its complexes.

\begin{tabular}{|c|c|c|c|c|c|c|c|}
\hline \multirow{2}{*}{ Assignments } & \multicolumn{7}{|c|}{ Compounds } \\
\hline & STG & $\operatorname{Mg}(\mathrm{II})$ & $\mathrm{Ca}(\mathrm{II})$ & $\mathrm{Cr}(\mathrm{III})$ & $\mathrm{Zn}(\mathrm{II})$ & $\mathrm{Cu}(\mathrm{II})$ & $\mathrm{Se}(\mathrm{IV})$ \\
\hline $\mathrm{N}-\mathrm{H}$ stretching & 3357 & 3300 & 3316 & 3340 & 3341 & 3305 & 3340 \\
\hline $\mathrm{C}-\mathrm{H}$ stretching & $\begin{array}{l}3059 \\
2917 \\
2850\end{array}$ & $\begin{array}{l}2918 \\
2850\end{array}$ & $\begin{array}{l}2917 \\
2849\end{array}$ & 2919 & $\begin{array}{l}2918 \\
2850\end{array}$ & $\begin{array}{l}2923 \\
2854\end{array}$ & $\begin{array}{l}2918 \\
2851\end{array}$ \\
\hline $\mathrm{C}=\mathrm{O}$ stretching & 1669 & - & - & - & - & - & - \\
\hline $\mathrm{C}=\mathrm{N}$ stretching & 1634 & 1645 & 1634 & 1652 & 1635 & 1644 & 1646 \\
\hline NH2 bending & 1609 & - & - & - & - & - & - \\
\hline $\mathrm{C}-\mathrm{C}$ and $\mathrm{C}-\mathrm{N}$ stretching & $\begin{array}{l}1556 \\
1514 \\
1426\end{array}$ & 1516 & $\begin{array}{l}1518 \\
1426\end{array}$ & $\begin{array}{l}1515 \\
1427\end{array}$ & $\begin{array}{l}1579 \\
1514 \\
1424\end{array}$ & $\begin{array}{l}1518 \\
1426\end{array}$ & $\begin{array}{l}1517 \\
1426\end{array}$ \\
\hline $\mathrm{CH}$ in plane bending & $\begin{array}{l}1324 \\
1274\end{array}$ & $\begin{array}{l}1335 \\
1311 \\
1275\end{array}$ & $\begin{array}{l}1336 \\
1277\end{array}$ & 1315 & $\begin{array}{l}1335 \\
1274\end{array}$ & $\begin{array}{l}1372 \\
1335 \\
1275\end{array}$ & 1315 \\
\hline C-F stretching & $\begin{array}{c}1146 \\
978\end{array}$ & $\begin{array}{l}1138 \\
1015\end{array}$ & 1056 & $\begin{array}{l}1159 \\
1013\end{array}$ & $\begin{array}{l}1107 \\
1013\end{array}$ & $\begin{array}{l}1140 \\
1048\end{array}$ & $\begin{array}{l}1107 \\
1013\end{array}$ \\
\hline $\mathrm{CH}$ out-of-plane bending & $\begin{array}{l}913 \\
881 \\
844 \\
725\end{array}$ & $\begin{array}{l}889 \\
848 \\
665\end{array}$ & 891 & $\begin{array}{l}950 \\
897 \\
664\end{array}$ & $\begin{array}{l}894 \\
667\end{array}$ & $\begin{array}{l}845 \\
621\end{array}$ & $\begin{array}{l}951 \\
897 \\
664\end{array}$ \\
\hline $\mathrm{M}-\mathrm{O}$ stretching & - & 504 & 515 & 556 & 557 & $\begin{array}{l}558 \\
515\end{array}$ & $\begin{array}{l}555 \\
519\end{array}$ \\
\hline M-N stretching & - & 446 & 476 & 445 & 477 & $\begin{array}{l}466 \\
445\end{array}$ & 440 \\
\hline
\end{tabular}

\subsubsection{X-ray Powder Diffraction Patterns, SEM and TEM Morphological Studies}

XRD, SEM, and TEM analyses showed the crystalline nature of the metal complexes. The samples of the solid STG complexes were characterized at room temperature by X-ray diffraction by using $\mathrm{Cu} \mathrm{K} \alpha$ radiation. A crystalline form of STG showed an Xray powder diffraction pattern with peaks at the 2-theta of 13.7, 18.0, 22.6, 25.7, and 27.0 degrees. The diffractograms of the $\mathrm{Mg}^{2+}, \mathrm{Ca}^{2+}, \mathrm{Cr}^{3+}, \mathrm{Zn}^{2+}, \mathrm{Cu}^{2+}$, and $\mathrm{Se}^{4+} \mathrm{STG}$ complexes showed distinguished patterns at $(14.94,22.75,25.35,26.59,30.27,32.62,40.22$, 49.40 , and 53.10 degrees), (22.75, 25.35, 26.61, 28.59, 30.28, 32.55, 32.96, 36.11, 40.15, 41.08, $47.42,49.27$, and 53.13), (22.43, 23.11, 25.45, 26.66, 28.67, 30.30, 32.87, 36.22, 40.17, and 53.09 degrees), (15.21, 22.75, 26.58, 28.51, 30.21, 32.75, 40.22, 49.27, and 52.96 degrees), (16.65, $21.11,22.06,22.54,25.22,26.46,28.64,28.64,30.11$, and 32.68 degrees), and (16.24, 19.39, $20.42,22.54,25.56,26.63,30.27,32.68,36.18$, and 53.10 degrees), respectively. Sharp, intense, and strong Bragg diffraction lines in the diffractograms of STG complexes were wellcharacterized and presented well-organized structures. The crystalline size of synthesized STG complexes was calculated using the Scherrer formula: $D=k \lambda / \beta \operatorname{Cos} \theta$ [32], where $k$ is a constant and equal to $0.94, \lambda$ is the used wavelength of $X$-ray $(0.154 \mathrm{~nm})$, and $\beta$ is a full width at half maximum peak of the XRD pattern [33]. The particle size of STG complexes was found to be within $50-120 \mathrm{~nm}$. It was observed that crystalline size is different for these complexes due to changes in metal ions. SEM images of the $\mathrm{Mg}(\mathrm{II}), \mathrm{Zn}(\mathrm{II}), \mathrm{Cu}(\mathrm{II})$, and Se(IV) STG complexes are shown in Figure 3A-D. From this figure, it can be see that the average lengths of the grains for these complexes are in the range of 5-50 $\mu \mathrm{m}$. The surface morphology was found to change with changes in metal ions, with the images having large numbers of irregularly shaped grains and smaller numbers of regularly shaped grains. It is quite clear from the results that the average grain size estimated by SEM was larger than the average grain size measured by XRD. TEM images of the $\mathrm{Mg}(\mathrm{II}), \mathrm{Ca}(\mathrm{II}), \mathrm{Cr}(\mathrm{III})$, 
$\mathrm{Zn}(\mathrm{II}), \mathrm{Cu}(\mathrm{II})$, and $\mathrm{Se}(\mathrm{IV})$ complex nanoparticles resulting from the complexes between metal chloride salts and two STG molecules are display in Figure 4A-F. After chelation, the particle size was found to be within the range of 50-100 nm with spherical black spots, which was in good agreement with X-ray powder diffraction data.
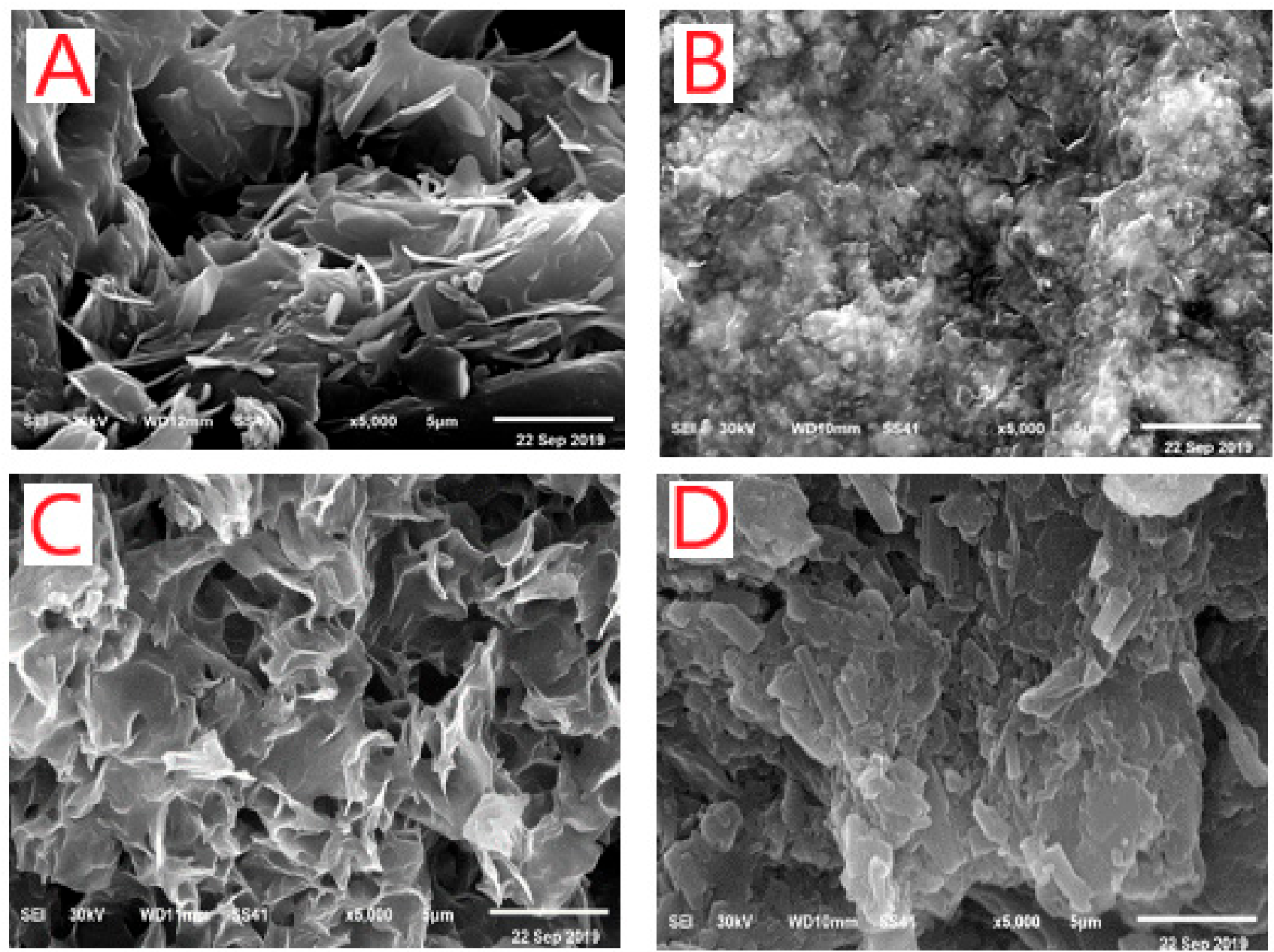

Figure 3. SEM images of (A) $\mathrm{Mg}(\mathrm{II})$, (B) $\mathrm{Zn}(\mathrm{II}),(\mathrm{C}) \mathrm{Cu}(\mathrm{II})$, and (D) Se(IV) STG complexes.

\subsubsection{Thermogravimetric Study}

The degradation profiles and thermal stabilities of the $\mathrm{Mg}^{2+}, \mathrm{Ca}^{2+}, \mathrm{Cr}^{3+}, \mathrm{Zn}^{2+}, \mathrm{Cu}^{2+}$, and $\mathrm{Se}^{4+}$ STG complexes were investigated by TGA measurements. Figure 5 and Table 3 show TGA thermograms and thermal degradation patterns of the complexes, respectively. $\mathrm{Cr}$ (III)-STG showed a better thermal stability $\left(686^{\circ} \mathrm{C}\right)$ than the other STG complexes. The TGA thermograms indicate that the $\mathrm{Mg}(\mathrm{II}), \mathrm{Ca}(\mathrm{II}), \mathrm{Zn}(\mathrm{II}), \mathrm{Cu}(\mathrm{II})$, and $\mathrm{Se}(\mathrm{IV}) \mathrm{STG}$ complexes are thermally stable up to $662,674,565,654$, and $330{ }^{\circ} \mathrm{C}$, respectively. It was observed that the calcium(II) STG complex; the $\mathrm{Mg}$ (II), $\mathrm{Cr}$ (III), and $\mathrm{Cu}$ (II) STG complexes; and the $\mathrm{Zn}$ (II) and Se(IV) STG complexes are thermally decomposed within four, three, and two endothermic steps, respectively. The thermogram of the STG complexes indicates that the most stable final product of the thermal degradation was metal oxide polluted with carbon atoms, except for that of selenium(IV), where there were no residual products because of the sublimation behavior of selenium at high temperatures. 

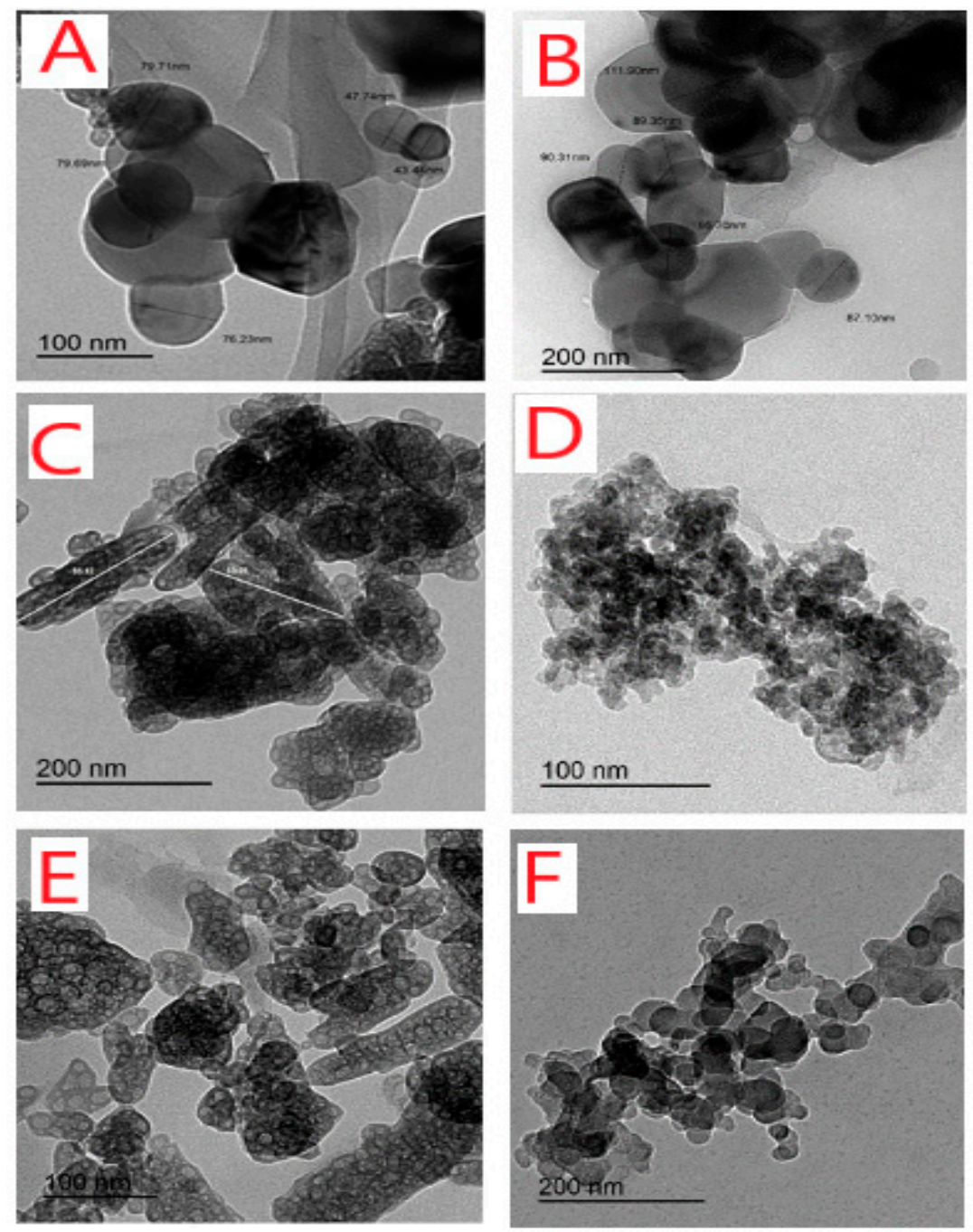

Figure 4. TEM images of (A) $\mathrm{Mg}$ (II), (B) Ca(II), (C) $\mathrm{Cr}(\mathrm{III}),(\mathbf{D}) \mathrm{Zn}$ (II), (E) $\mathrm{Cu}(\mathrm{II})$, and (F) Se(IV) STG complexes.

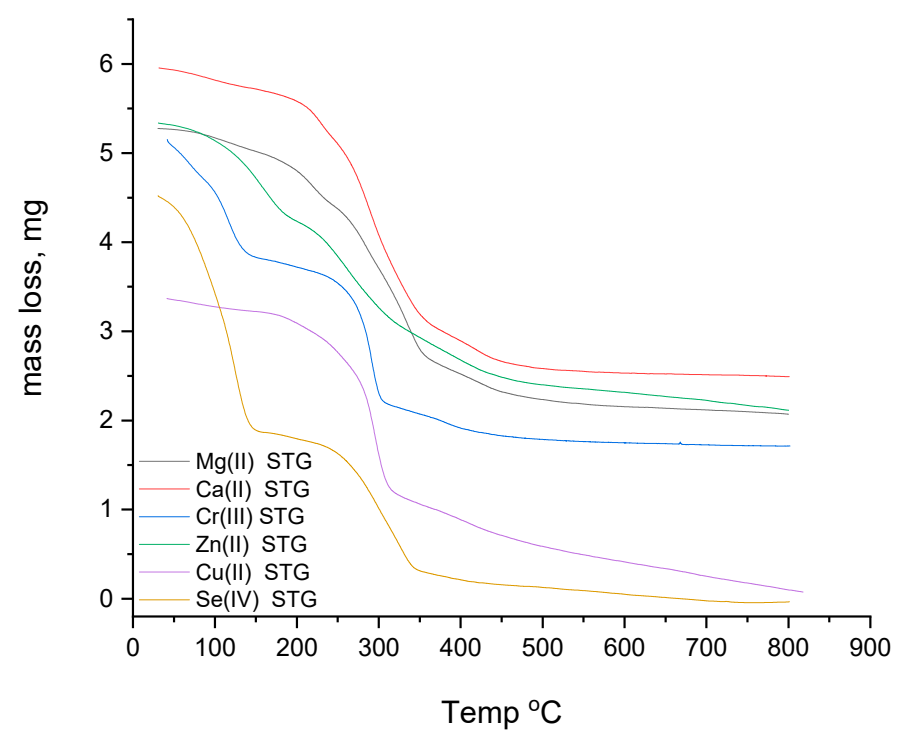

Figure 5. TGA curves of $\mathrm{Mg}(\mathrm{II}), \mathrm{Ca}(\mathrm{II}), \mathrm{Cr}(\mathrm{III}), \mathrm{Zn}(\mathrm{II}), \mathrm{Cu}(\mathrm{II})$, and $\mathrm{Se}(\mathrm{IV}) \mathrm{STG}$ complexes. 
Table 3. Thermal data of the STG complexes.

\begin{tabular}{|c|c|c|c|c|c|c|}
\hline \multirow[t]{2}{*}{ Complexes } & \multirow[t]{2}{*}{ Steps } & \multirow{2}{*}{$\begin{array}{c}\text { Temp. } \\
\text { Range }\left({ }^{\circ} \mathrm{C}\right)\end{array}$} & \multirow{2}{*}{$\begin{array}{c}\text { DTA } \\
\text { Peak }\left({ }^{\circ} \mathrm{C}\right)\end{array}$} & \multicolumn{2}{|c|}{$\begin{array}{c}\text { TGA } \\
\text { Weight Loss (\%) }\end{array}$} & \multirow[t]{2}{*}{ Assignments } \\
\hline & & & & Calc. & Found & \\
\hline \multirow{3}{*}{ Mg(II) STG } & 1 st & \multirow{3}{*}{$\begin{array}{c}30-250 \\
250-800\end{array}$} & \multirow{3}{*}{$\begin{array}{c}84,222 \\
662\end{array}$} & 17.58 & 17.50 & $6 \mathrm{H}_{2} \mathrm{O}$ and $\mathrm{Cl}_{2}$ \\
\hline & 2nd & & & 50.50 & 50.28 & 2STG molecule \\
\hline & Residual & & & 31.92 & 32.22 & $\mathrm{MgO}$ and polluted carbon \\
\hline \multirow{3}{*}{$\mathrm{Ca}(\mathrm{II}) \mathrm{STG}$} & $1 s t$ & \multirow{3}{*}{$\begin{array}{c}30-250 \\
250-800\end{array}$} & \multirow{3}{*}{$\begin{array}{c}80,225 \\
425,674\end{array}$} & 7.67 & 7.45 & $\mathrm{Cl}_{2}$ \\
\hline & 2nd & & & 56.33 & 56.47 & 2STG molecule \\
\hline & Residual & & & 36.00 & 36.08 & $\mathrm{CaO}$ and polluted carbon \\
\hline \multirow{3}{*}{ Cr(III) STG } & $1 \mathrm{st}$ & \multirow{3}{*}{$\begin{array}{c}30-300 \\
300-800\end{array}$} & \multirow{3}{*}{$\begin{array}{c}74,294 \\
686\end{array}$} & 19.84 & 19.60 & $6 \mathrm{H}_{2} \mathrm{O}$ and ${ }^{3} /{ }^{2} \mathrm{Cl}_{2}$ \\
\hline & 2nd & & & 47.10 & 47.14 & 2STG molecule \\
\hline & Residual & & & 33.06 & 33.26 & $\frac{1}{2} \mathrm{Cr}_{2} \mathrm{O}_{3}$ and polluted carbon \\
\hline \multirow{3}{*}{$\mathrm{Zn}(\mathrm{II}) \mathrm{STG}$} & 1st & \multirow{3}{*}{$\begin{array}{c}30-120 \\
120-800\end{array}$} & \multirow{3}{*}{$\begin{array}{c}78 \\
565\end{array}$} & 7.47 & 7.35 & $\mathrm{Cl}_{2}$ \\
\hline & 2nd & & & 58.20 & 58.44 & 2STG molecule \\
\hline & Residual & & & 34.06 & 34.21 & $\mathrm{ZnO}$ and polluted carbon \\
\hline \multirow{3}{*}{$\mathrm{Cu}(\mathrm{II}) \mathrm{STG}$} & $1 \mathrm{st}$ & \multirow{3}{*}{$\begin{array}{c}30-350 \\
350-800\end{array}$} & \multirow{3}{*}{$\begin{array}{c}184,294 \\
654\end{array}$} & 10.86 & 10.60 & $2 \mathrm{H}_{2} \mathrm{O}$ and $\mathrm{Cl}_{2}$ \\
\hline & 2nd & & & 55.11 & 55.30 & 2STG molecule \\
\hline & Residual & & & 34.03 & 34.10 & $\mathrm{CuO}$ and polluted carbon \\
\hline \multirow{2}{*}{ Se(IV) STG } & 1st & \multirow{2}{*}{$30-800$} & \multirow{2}{*}{90,330} & 100 & 100 & $2 \mathrm{Cl}_{2}$ and $2 \mathrm{STG}$ \\
\hline & Residual & & & 0.0 & 0.0 & Selenium metal sublimated \\
\hline
\end{tabular}

\subsection{Biology Part}

\subsubsection{Results}

The untreated diabetic group (STZ group) had the highest blood glucose and $\mathrm{Hb} \mathrm{A} 1 \mathrm{c}$ levels of all groups. In addition, this group had the lowest insulin and c-peptide levels of all groups as shown in Table 4 .

Table 4. Comparison of the studied groups in blood glucose, insulin, $\mathrm{HbA} 1 \mathrm{C}$, and fasting serum C-peptide levels.

\begin{tabular}{|c|c|c|c|c|}
\hline Groups & Blood Glucose (mg/dL) & $\begin{array}{l}\text { Insulin } \\
\text { (uIU/mL) }\end{array}$ & $\begin{array}{c}\text { HbA1C } \\
(\mathrm{mmol} / \mathrm{mol})\end{array}$ & $\begin{array}{c}\text { Fasting Serum } \\
\text { C-Peptide }(\mathrm{ng} / \mathrm{mL})\end{array}$ \\
\hline $\begin{array}{l}\text { Group } 1 \\
\text { (Control) }\end{array}$ & $87.4 \pm 1.9$ & $25.1 \pm 0.6$ & $3.2 \pm 0.3$ & $4.2 \pm 0.1$ \\
\hline $\begin{array}{l}\text { Group } 2 \\
\text { (STZ) }\end{array}$ & $377.3 \pm 4.0 *$ & $4.2 \pm 0.3 *$ & $9.2 \pm 0.2 *$ & $0.5 \pm 0.06^{*}$ \\
\hline $\begin{array}{c}\text { Group } 3 \\
\text { (STZ and STG) }\end{array}$ & $141.6 \pm 4.0 * \#$ & $18.9 \pm 1.3 * \#$ & $5.0 \pm 0.5 * \#$ & $2.6 \pm 0.3 * \#$ \\
\hline $\begin{array}{c}\text { Group } 4 \\
(\mathrm{STZ} \text { and STG/Cu) }\end{array}$ & $130.8 \pm 3.8$ *\# & $19.8 \pm 1.5 * \#$ & $3.0 \pm 0.2 \#$ & $3.3 \pm 0.3 * \#$ \\
\hline $\begin{array}{c}\text { Group } 5 \\
(\mathrm{STZ} \text { and STG/Mg) }\end{array}$ & $128.98 \pm 2.58 \#$ & $20.58 \pm 1.08 \#$ & $3.1 \pm 0.08 \#$ & $3.80 \pm 0.6 \#$ \\
\hline $\begin{array}{c}\text { Group } 6 \\
(\mathrm{STZ} \text { and STG/Zn) }\end{array}$ & $95.4 \pm 2.9 \#$ & $23.5 \pm 0.6 \#$ & $3.3 \pm 0.5 \#$ & $4.1 \pm 0.4 \#$ \\
\hline $\begin{array}{c}\text { Group } 7 \\
(\mathrm{STZ} \text { and STG/Ca) }\end{array}$ & $110 \pm 3.58 \#$ & $22.39 \pm 2.01 \#$ & $4.05 \pm 0.36 \#$ & $2.50 \pm 0.63 \#$ \\
\hline $\begin{array}{c}\text { Group } 8 \\
(\mathrm{STZ}+\mathrm{STG} / \mathrm{Cr})\end{array}$ & $90.24 \pm 3.68 \#$ & $23.68 \pm 1.88 \#$ & $3.01 \pm 0.69 \#$ & $3.98 \pm 0.87 \#$ \\
\hline $\begin{array}{c}\text { Group } 9 \\
\text { (STZ and STG/Se) }\end{array}$ & $100.69 \pm 2.69 \#$ & $21.02 \pm 1.69 \#$ & $3.68 \pm 0.39 \#$ & $3.21 \pm 0.63 \#$ \\
\hline$p$-value & $<0.001$ (HS) & $<0.001$ (HS) & $<0.001(\mathrm{HS})$ & $<0.001$ (HS) \\
\hline
\end{tabular}

Data are presented as mean \pm SD. * Significant difference compared to control group; \# Significant difference compared to STZ group. HS: highly significant. 
Compared to the control group, group 3 (STZ and STG) and group 4 (STZ and STG / Cu) had significantly higher blood glucose levels, and they had significantly lower insulin and c-peptide levels. However, there were no statistically significant differences between the control group and group 4 (STZ and STG/Cu) in $\mathrm{Hb}$ A1c. There were no statistically significant differences between the control group and groups 5, 6, 7, 8, and 9 regarding blood glucose, $\mathrm{Hb} \mathrm{A} 1 \mathrm{c}$, insulin, and c-peptide levels.

Oxidative Stress Enzymatic and Non-Enzymatic Biomarkers

The untreated diabetic group (STZ group) had the highest MDA level of all groups. In addition, it had the lowest GPX, CAT, and SOD levels of all groups as shown in Table 5. Compared to the control group, group 3 (STZ and STG) and group 4 (STZ and STG/Cu) had significantly higher MDA levels, and they had significantly lower GPX and CAT levels. However, there were no statistically significant differences between the control group and group 4 (STZ and STG/Cu) in SOD. There were no statistically significant differences between the control group and groups 5, 6, 7, 8, and 9 regarding GPX, CAT, MDA, and SOD levels.

Table 5. Comparison of the studied groups in pancreatic GPX, CAT, MDA, and SOD levels.

\begin{tabular}{|c|c|c|c|c|}
\hline Groups & $\begin{array}{l}\text { GPX } \\
(U / g)\end{array}$ & $\begin{array}{l}\text { CAT } \\
\text { (U/g) }\end{array}$ & $\begin{array}{l}\text { MDA } \\
(\mathrm{U} / \mathrm{g})\end{array}$ & $\begin{array}{l}\text { SOD } \\
(U / g)\end{array}$ \\
\hline $\begin{array}{l}\text { Group } 1 \\
\text { (Control) }\end{array}$ & $34.1 \pm 3.0$ & $1.7 \pm 0.2$ & $3.1 \pm 0.2$ & $21.5 \pm 1.2$ \\
\hline $\begin{array}{l}\text { Group } 2 \\
\text { (STZ) }\end{array}$ & $7.4 \pm 0.2^{*}$ & $0.24 \pm 0.05 *$ & $80.3 \pm 1.2 *$ & $5.4 \pm 0.3 *$ \\
\hline $\begin{array}{c}\text { Group } 3 \\
\text { (STZ and STG) }\end{array}$ & $20.9 \pm 1.5$ *\# & $1.0 \pm 0.2 * \#$ & $20.0 \pm 0.8^{*} \#$ & $14.0 \pm 0.8 * \#$ \\
\hline $\begin{array}{c}\text { Group } 4 \\
(\mathrm{STZ} \text { and STG/Cu) }\end{array}$ & $22.06 \pm 0.68 * \#$ & $1.03 \pm 0.01 * \#$ & $17.68 \pm 0.85^{* \#}$ & $17.29 \pm 1.25 \#$ \\
\hline $\begin{array}{c}\text { Group } 5 \\
\text { (STZ and STG/Mg) }\end{array}$ & $24.88 \pm 0.45 \#$ & $1.45 \pm 0.1 \#$ & $10.02 \pm 1.36 \#$ & $18.05 \pm 1.59 \#$ \\
\hline $\begin{array}{c}\text { Group } 6 \\
\text { (STZ and STG/Zn) }\end{array}$ & $31.0 \pm 1.6 \#$ & $1.60 \pm 0.3 \#$ & $7.9 \pm 0.7 \#$ & $19.9 \pm 1.3 \#$ \\
\hline $\begin{array}{c}\text { Group } 7 \\
\text { (STZ and STG/Ca) }\end{array}$ & $29.58 \pm 1.78 \#$ & $1.54 \pm 0.02 \#$ & $8.05 \pm 1.58 \#$ & $19.05 \pm 1.36 \#$ \\
\hline $\begin{array}{c}\text { Group } 8 \\
\text { (STZ and STG/Cr) }\end{array}$ & $32.17 \pm 2.36 \#$ & $1.68 \pm 0.05 \#$ & $4.98 \pm 1.02 \#$ & $20.54 \pm 1.98$ \# \\
\hline $\begin{array}{c}\text { Group } 9 \\
\text { (STZ and STG/Se) }\end{array}$ & $30.25 \pm 2.58 \#$ & $1.34 \pm 0.04 \#$ & $5.25 \pm 1.32 \#$ & $19.85 \pm 2.05 \#$ \\
\hline$p$-value & $<0.001$ (HS) & $<0.001$ (HS) & $<0.001$ (HS) & $<0.001$ (HS) \\
\hline
\end{tabular}

Data are presented as mean \pm SD. * Significant difference compared to the control group; \# Significant difference compared to the STZ group. HS: highly significant.

Histological Examination

Figure 6 shows a photomicrograph of the control group, which reveals that pancreatic tissues showed the normal appearance of islets of Langerhans. Figure 6B shows an STZtreated group with detached pancreatic parenchyma and the disappearance of islets of Langerhans (red arrow). Figure 6C shows the STZ and STG group with the restoration of detached pancreatic parenchyma with moderately sized islets of Langerhans. Figure 6D-F shows the STZ and $\mathrm{Cu} / \mathrm{STG}, \mathrm{Mg}$, and Zn group with normal pancreatic parenchyma and the appearance of highly enlarged islets of Langerhans. The histological index scoring, used to clarify the pancreatic structural changes, is shown in Table 6. 

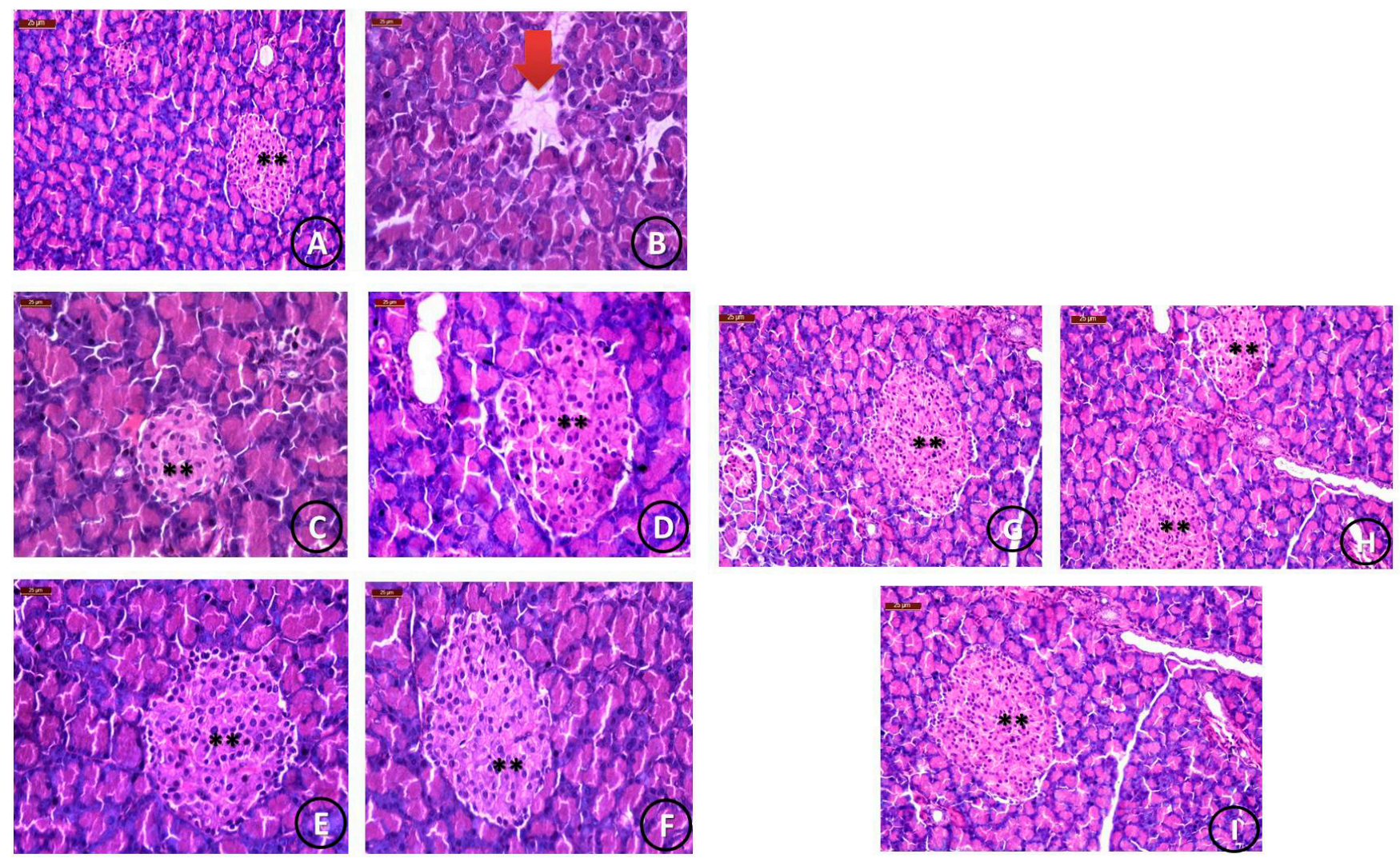

Figure 6. Histological photomicrographs of pancreatic tissues. (A) Normal pancreatic parenchyma and the normal appearance of islets of Langerhans $\left(^{* *}\right)($ scale bar $=25 \mu \mathrm{m})$. (B) STZ group showing detached pancreatic parenchyma $(* *)$ with the disappearance of islets of Langerhans (red arrow) (scale bar $=25 \mu \mathrm{m}$ ). (C) STZ and STG group showing the restoration of detached pancreatic parenchyma with moderately sized islets of Langerhans $(* *)($ scale bar $=25 \mu \mathrm{m})$. (D-I) STZ and Mg, Cu, Zn, Ca, Cr, and Se/STG groups showing normal pancreatic parenchyma (with the appearance of islets of Langerhans ${ }^{* *}$ ) that were greatly enlarged in groups D and F) and enlarged pancreatic islets in group $\mathrm{H}$, which was treated with the Cr/STG novel complex (scale bar $=25 \mu \mathrm{m}$ ).

\subsubsection{Discussion}

Interestingly, a key challenge in the use of STG for the long-term control and management of type II DM is its adverse effects on the exocrine part of pancreatic tissues, including the induction of acute pancreatitis [34]. Due to the clinical significance and seriousness of pancreatitis, the present study was designed to assess the acute biological effects of STG treatment on exocrine and endocrine pancreatic tissues, as well as to investigate the synergistic and therapeutic action of novel STG-metal complexes.

This study concerned the use of STG and its metal complexes $\mathrm{Cu} / \mathrm{STG}, \mathrm{Mg} / \mathrm{STG}$, and $\mathrm{Zn} / \mathrm{STG}$ in the treatment of diabetic rats induced by STZ. We tried to reveal the pros and cons of each treatment separately and in combination, as well as the possible improving effect of metals after their addition to STG. A novelty in the current study was the use of novel STG complexes in treatments against diabetic pancreatic complications.

The untreated diabetic animals suffered from increases of blood glucose and $\mathrm{Hb} \mathrm{A} 1 \mathrm{c}$ levels, as well as decreases of insulin and fasting C-peptide levels. Additionally, pancreatic MDA levels were increased, and all the measured antioxidant enzymes (CAT, SOD, GRx, and GST) significantly decreased. Hyperglycemia leads to severe oxidative stress damage that further accelerates the development of diabetes mellitus. The histological examination of pancreatic tissues revealed reductions in the number and size of the Langerhans islets, as well as their disappearance in major fields of examination with the detachment of pancreatic parenchyma. 
Table 6. Histopathological findings in the pancreatic tissues of normal rats, untreated diabetic rats, and diabetic rats treated with either STG, Cu/STG, Mg/STG, or Zn/STG.

\begin{tabular}{|c|c|c|c|c|c|c|}
\hline \multirow{2}{*}{ Groups } & \multicolumn{2}{|c|}{ Pancreatic Parenchyma } & \multicolumn{4}{|c|}{ Islets of Langerhans Size } \\
\hline & Normal & Detached & Normal & Reduced & Mild & Enlarged \\
\hline $\begin{array}{l}\text { Group } 1 \\
\text { (Control) }\end{array}$ & $90 \%$ & $0 \%$ & $90 \%$ & $0 \%$ & $0 \%$ & $0 \%$ \\
\hline $\begin{array}{l}\text { Group } 2 \\
\text { (STZ) }\end{array}$ & $0 \%$ & $90 \%$ & $0 \%$ & $90 \%$ & $25 \%$ & $0 \%$ \\
\hline $\begin{array}{c}\text { Group } 3 \\
(\mathrm{STZ}+\mathrm{STG})\end{array}$ & $80 \%$ & $25 \%$ & $80 \%$ & $0 \%$ & $80 \%$ & $80 \%$ \\
\hline $\begin{array}{c}\text { Group } 4 \\
(\mathrm{STZ}+\mathrm{STG} / \mathrm{Cu})\end{array}$ & $90 \%$ & $0 \%$ & $90 \%$ & $0 \%$ & $25 \%$ & $90 \%$ \\
\hline $\begin{array}{c}\text { Group } 5 \\
(\mathrm{STZ}+\mathrm{STG} / \mathrm{Mg})\end{array}$ & $90 \%$ & $0 \%$ & $90 \%$ & $0 \%$ & $25 \%$ & $90 \%$ \\
\hline $\begin{array}{c}\text { Group } 6 \\
(\mathrm{STZ}+\mathrm{STG} / \mathrm{Zn})\end{array}$ & $90 \%$ & $0 \%$ & $90 \%$ & $0 \%$ & $25 \%$ & $90 \%$ \\
\hline $\begin{array}{c}\text { Group } 7 \\
(\mathrm{STZ}+\mathrm{STG} / \mathrm{Ca})\end{array}$ & $90 \%$ & $0 \%$ & $90 \%$ & $0 \%$ & $25 \%$ & $90 \%$ \\
\hline $\begin{array}{c}\text { Group } 8 \\
\text { (STZ+STG/Cr) }\end{array}$ & $90 \%$ & $0 \%$ & $90 \%$ & $0 \%$ & $25 \%$ & $90 \%$ \\
\hline $\begin{array}{c}\text { Group } 9 \\
\text { (STZ+ STG/Se) }\end{array}$ & $90 \%$ & $0 \%$ & $90 \%$ & $0 \%$ & $25 \%$ & $90 \%$ \\
\hline
\end{tabular}

Data are expressed as percentages of change.

In the current study, treatment with metal complexes $(\mathrm{Cu}, \mathrm{Mg}$, and $\mathrm{Zn})$ of STG revealed significant improvements in all above-mentioned parameters compared to the untreated diabetic group.

This study produced results that corroborate many of the findings of the previous work of Kelany et al. [35], who reported that an STG-insulin combination better produced hypoglycemic and protective effects and ameliorated oxidative stress than either drug alone. This combination might have clinical efficacy in uncontrolled type 2 diabetes and confirms the obtained results, which showed that the used metals ameliorate the anti-diabetic effects of STG and may enhance its antioxidant activities.

STZ destroys some of the $\beta$-cells of islets of Langerhans, thus resulting in increases of blood glucose levels and thus insulin secretion inhibition. These destructive effects are mostly due to the reduction of glucose entry into adipose tissues and muscles, as well as the increase of glycogen breakdown and glucose production caused by the hepatic tissues [36]. STZ also exhibited reductions of pancreatic islets through the excessive production of reactive oxygen species. These current findings coincide with previously published results [37].

In the current study, STG-metal complexes were able to increase the activity of antioxidant enzymes and enhance antioxidant capacity. This antioxidant effect could be attributed to decreasing lipid peroxidation [38]. This finding was in accordance with that of Bao et al. [39], who attributed the antioxidant effects of STG due to DPP-4 inhibitors that increase GLP-1 levels, since this effect could be blocked by a GLP-1 receptor antagonist. Additionally, GLP-1 was found to activate an AMP-activated protein kinase that, in turn, enhanced the activity of the antioxidant enzymes and lead to a significant improvement of oxidative stress-an effect that was duplicated due to the interaction of the chelated metals and STG.

In humans, most obese individuals with insulin-resistance have shown increases of their insulin secretion and are non-diabetic [40]. Recently, $\beta$-cell dysfunction was found to participate in the development and progress of diabetes mellitus due to the failure of the $\beta$-cells to compensate for the release of insulin during the insulin resistance process [41]. 
Impaired $\beta$-cell function and insulin resistance are considered to be the hallmarks of type II DM pathogenesis [42]. An STZ, high-fat diet-fed (STZ/HFD) experimental type 2 DM rat model was used to mimic the diabetes mellitus pathology; it was found that HFD induced insulin resistance and a low dose of STZ caused the partial impairment of $\beta$-cell function [43].

Our results regarding the effects of STG on pancreatic tissues and the novel effect of STG-metal complexes in controlling STZ/HFD-induced diabetes mellitus in rats showed that there were great differences in the biochemical and histological findings obtained from the diabetic rats orally receiving STG and those receiving STG-metal complexes $(\mathrm{Cu}, \mathrm{Mg}$, or Zn), and the best improvement was recorded in the Zn/STG treated diabetic group.

We expect that the great improvement in the diabetic group treated with Zn/STG can be attributed to the importance of zinc as a major element for growth that plays a major role in cellular division. In mammalian pancreatic tissues, $\mathrm{Zn}$ is an essential element for the correct secretion and action of insulin in $\beta$-cells [44].

Insulin is stored inside secretory vesicles, where two zinc ions coordinate six insulin monomers to form a hexameric structure upon which maturated insulin crystals are based. Changes in zinc levels in pancreatic tissues have been found to be associated with diabetes mellitus. As such, the relationship between zinc and insulin is undoubtedly critical and essential to normal $\beta$-cell function. When the exocytosis of insulin occurs, insulin granules fuse with $\beta$-cells and release their contents, i.e., insulin and an amount of free zinc, into the extracellular space and local circulation [44]. This evidence indicates the great success of our novel Zn/STG complex in alleviating a diabetic state and improving $\beta$-cells size and effectiveness, as noticed in the histological sections of pancreatic tissues.

We also found that our novel Mg/STG, Cu/STG, and Zn/STG complexes can induce decreases of hyperglycemia and improvements of the antioxidant activities of pancreatic tissues homogenates, and these ameliorative effects may be attributed to the SOD enzymeeither the manganese-containing MnSOD (present in the mitochondria) or the dinuclear $\mathrm{Cu} / \mathrm{Zn}-\mathrm{SOD}$ (present in the cytosol and extracellular space) - that performs the role of superoxide detoxification in normal cells and tissues. SOD deficiency has been shown to be associated with development of inflammatory processes [45], and our novel STG-metal complexes greatly improve SOD enzymes levels, thus providing great potency for the antioxidant cellular defense systems of pancreatic tissues and improving the secretion and effect of insulin.

Attempts to use the SOD enzyme itself as a therapeutic agent have been partially successful in animals, but not in humans [46]. Pharmacokinetic problems, including delivery problems and the short half-life of SOD in the blood, are major obstacles to the use of antioxidant enzymes in humans. Thus, we tried to use an anti-diabetic drug (STG) in combination with small-molecule metals $(\mathrm{Cu}, \mathrm{Mg}$, and $\mathrm{Zn})$ to increase the hypoglycemic effect of STG and mimic that of natural enzymes such as SOD, which may have similar chemistry and thus be useful in treating diseases under safe biological conditions, low toxicity, and favorable bio- distribution.

The present findings further support the previously reported idea that several mechanisms may be involved in the pathogenesis of diabetes mellitus, such as the accumulation of AGEs and increases of the oxidative stress pathway, as confirmed in the current study in the untreated diabetic group [47]. These oxidative stress pathways cause an imbalance in the mitochondrial redox state of a cell and lead to the excessive formation of reactive oxygen species. Moreover, hyperglycemia causes multi-degeneration through increased oxidative stress, which alters the metabolism and dysfunction in diabetic conditions [48].

Oxidative stress is not only a secondary manifestation of diabetes mellitus but also the first cause of a series of complications involved in diabetes mellitus [38]. The present findings agree with this characterization and are supported by our use of novel STG-metal complexes that may present a proper therapeutic approach to prevent the complications of diabetes, wherein we concentrate on early glycemic control and reducing oxidative stress. 
Manganese (Mn) is a major nutrient that is very important to metabolism, especially that of proteins, and cellular protection from oxidative stress and free radicals. Mn is also a significant biological metal due to its presence in the active center of many antioxidant enzymes. Recently, many bioinorganic chemists have developed novel metallodrugs with manganese-based compounds because previous studies had demonstrated that $\mathrm{Mn}^{2+}$ supplementation can lower markers of oxidative stress and endothelial dysfunction, thereby lowering diabetes mellitus pathophysiological complications, as confirmed in the current study regarding the complexation of STG with Mn [49].

Oxidative stress is not only a manifestation of diabetes but also the first cause of the cascade of complications involved in diabetic pathology. The present findings agree with this idea and are supported by the current conviction that the proper therapeutic approach with novel STG-metal complexes to prevent complications of diabetes is to concentrate on glycemic control and decreasing oxidative stress [50]. Some of these pathophysiologic mechanisms are potentially modifiable by DPP-IV inhibition [50-52]. In addition, Salcedo et al. [53] reported that GLP-1-based anti-diabetic drugs can be an effective new strategy to not only regulate blood glucose but also decrease the apoptotic cellular death of pancreatic $\beta$-cells, which is in complete agreement with the current findings.

The main goals of anti-diabetic drugs are to decrease blood glucose levels and to minimize the pathophysiological complications of diabetes mellitus [54]. However, the response to these drugs can show differences due to the multifactorial nature and aspects of type II diabetes mellitus pathophysiology [52].

Calcium intake is inversely associated with the development of type II diabetes, and the benefit of this nutrient appear to be additive [53]. For calcium, intake from supplements rather than from diets is significantly associated with a lower risk of type 2 diabetes. To our knowledge, this is the first prospective study to report complexations between STG and metals (Ca, $\mathrm{Mg}, \mathrm{Zn}, \mathrm{Cr}, \mathrm{Cu}$, and Se), as well as their effects on calcium intake and risk of incident type 2 diabetes, and it is the first to examine the combined effects of this novel $\mathrm{Ca} / \mathrm{STG}$ complex on diabetes risk.

Chromium is an essential mineral that is thought to be necessary for normal glucose and lipid homeostasis [55]. Chromium (III) is known as a glucose tolerance factor when in a complex, and it is considered to be biologically active. Severe chromium deficiency is known to cause reversible insulin resistance and diabetes [56]. Manufacturers have aggressively promoted the benefits of chromium in the prevention and treatment of insulin resistance and its associated conditions (type II diabetes, dyslipidemia, and cardiovascular disease), a strategy that agrees with the obtained results that confirmed the role of Cr/STG in reducing blood glucose levels and improving antioxidant enzyme capacities, as well as examining the histological structures of the pancreatic tissues.

Other factors that confirm the role of Se in alleviating the pathogenesis of diabetes mellitus is the participation of minerals in the pathogenesis of insulin resistance and their involvement in the synthesis of insulin [57]. Se is an anti-inflammatory and antioxidant micronutrient [56] that is essential for the insulin-signaling pathway, and it has great role in insulin-resistance mechanisms. Evidence has shown that suitable Se concentrations play key roles in the secretion of insulin and its actions.

The finding broadly supports the work [57], the authors of which suggested a quercetin/ sitagliptin combination as a promising therapeutic for the attenuation of doxorubicininduced testicular toxicity in rats, as well as that the main mechanism involved in such an effect may be due to the combined antioxidant and anti-inflammatory properties of both agents, thus proving the idea that complexation between STG and other metals can enhance their capacities.

The oral administration of STG and STG-metal complexes (either Mg, Cu, Zn, Ca, $\mathrm{Cr}$, or Se) at the tested doses significantly decreased blood glucose levels and led to great improvements in glycemic control, additionally evidenced by the amelioration of the levels of insulin. However, the STG-metal complexes led to the better control of blood glucose 
levels than STG alone. This could explain the potential synergistic effect of STG on blood glucose homeostasis when combined with metals [58].

\section{Conclusions}

Our results confirmed that all the used STG-metal complexes were efficient and safe for the treatment of hyperglycemia and oxidative injury induced by diabetes mellitus, with more antioxidant potency and insulin promotion in the case of treatment with both $\mathrm{Zn}$ and Se/STG complexes and greater improvements of glycemic state with the $\mathrm{Cr} / \mathrm{STG}$ complex. These results open new avenues to develop therapeutic strategies for diabetes mellitus and, potentially, the prevention of its associated complications.

Author Contributions: Conceptualization, S.M.E.-M., M.S.R. and R.Z.H.; Data curation, S.M.E.-M., M.S.R., F.A.A.-S. and R.Z.H.; Formal analysis, S.M.E.-M., F.A.A.-S. and M.S.R.; Investigation, S.M.E.-M. and M.S.R.; Methodology, S.M.E.-M., M.S.R. and R.Z.H.; Project administration, S.M.E.-M.; Resources, R.Z.H. and F.A.A.-S.; Supervision, R.Z.H.; Validation, S.M.E.-M. and R.Z.H.; Visualization, S.M.E.-M.; Writing-review \& editing, R.Z.H. All authors have read and agreed to the published version of the manuscript.

Funding: This research received no external funding.

Institutional Review Board Statement: The study was conducted according to the guidelines of the Declaration of Helsinki, and approved by Taif University Ethical Committee (approval number: 42-0074).

Informed Consent Statement: Not applicable.

Data Availability Statement: The data that support the findings of this study are available from the corresponding author upon reasonable request.

Acknowledgments: Taif University Researches Supporting Project number (TURSP-2020/21), Taif University, Taif, Saudi Arabia.

Conflicts of Interest: The authors declare no conflict of interest.

\section{References}

1. Anastassopoulou, J.; Theophanides, T. The Role of Metal Ions in Biological Systems and Medicine. In Bioinorganic Chemistry; Kessissoglou, D.P., Ed.; NATO ASI Series (Series C: Mathematical and Physical Sciences); Springer: Dordrecht, The Netherlands, 1995; Volume 459. [CrossRef]

2. Refat, M.S.; El-Shazly, S.A. Identification of a new anti-diabetic agent by combining $\mathrm{VOSO}_{4}$ and vitamin E In a single molecule: Studies on its spectral, thermal and pharmacological properties. Eur. J. Med. Chem. 2010, 45, 3070-3079. [CrossRef] [PubMed]

3. Refat, M.S.; Sharshar, T.; Elsabawy, K.M.; El-Sayed, M.Y.; Adam, A.M.A. Synthesis of new drug model has an effective antimicrobial and antitumors by combination of cephalosporin antibiotic drug with silver(I) ion in nano scale range: Chemical, physical and biological studies. J. Mol. Liq. 2017, 244C, 169-181. [CrossRef]

4. $\quad$ El-Megharbel, S.M.; Hamza, R.Z.; Almalki1, A.S.A.; Gobouri, A.A.; Alhadhrami, A.; Refat, M.S. Synthesis and speculated of new gold(III) melatonin nanometric complex structure: Drug model for testicular protection. Future Med. Chem. 2018, 10, 1693-1704. [CrossRef]

5. Hamza, R.Z.; EL-Megharbel, S.M.; Altalhi, T.; Gobouri, A.A.; Alrogi, A.A. Hypolipidemic and hepatoprotective synergistic effects of selenium nanoparticles and vitamin. E against acrylamide-induced hepatic alterations in male albino mice. Appl. Organomet. Chem. 2020, 34, e5458. [CrossRef]

6. $\quad$ El-Megharbel, S.M.; Hamza, R.Z.; Refat, M.S. Preparation, spectroscopic, thermal, antihepatotoxicity, hematological parameters and liver antioxidant capacity characterizations of $\mathrm{Cd}(\mathrm{II}), \mathrm{Hg}(\mathrm{II})$, and $\mathrm{Pb}(\mathrm{II})$ mononuclear complexes of paracetamol antiinflammatory drug. Spectrochim. Acta Part A 2014, 131C, 534-544. [CrossRef]

7. El-Megharbel, S.M.; Hamza, R.Z.; Refat, M.S. Synthesis, chemical identification and immunological evaluation studies of a novel silver(I) carbocysteine complex. Chem. Biol. Interact. 2014, 220, 169-180. [CrossRef] [PubMed]

8. El-Megharbel, S.M.; Hamza, R.Z.; Refat, M.S. Synthesis, spectroscopic and thermal characterizations of vanadyl (II) adenine complex prospective as antidiabetic drug agent. Spectrochim. Acta Part A 2015, 135, 850-864. [CrossRef]

9. $\quad$ El-Megharbel, S.M.; Hamza, R.Z.; Refat, M.S. Synthesis, spectroscopic and thermal studies of Mg(II), $\mathrm{Ca}$ (II), Sr(II) and Ba(II) diclofenac sodium complexes as anti-inflammatory drug and their protective effects on renal functions impairment and oxidative stress. Spectrochim. Acta Part A 2015, 135, 915-928. [CrossRef] 
10. Refat, M.S.; El-Megharbel, S.M.; Hussien, M.A.; Hamza, R.Z.; Al-Omar, M.A.; Naglah, A.M.; Afifi, W.M.; Kobeasy, M.I. Spectroscopic, structural characterizations and antioxidant capacity of the chromium(III) niacinamide compound as a diabetes mellitus drug mode. Spectrochim. Acta Part A 2017, 173C, 122-131. [CrossRef]

11. Anastassopoulou, J.; Collery, P.; Etienne, J.-C.; Theophanides, T. Metal Ions in Biology and Medicine; John Libbey Eurotext: Paris, France; London, UK, 1992; Volume 2.

12. Waker, W.E.C.; Vallee, B.L. Nucleic acids and metals I. Chromium, manganese, nickel, iron, and other metals in ribonucleic acid from diverse biological sources. J.Biol. Chem. 1959, 234, 3257.

13. Vaghasiya, J.; Sheth, N.; Bhalodia, Y.; Manek, R. Sitagliptin protects renal ischemia reperfusion induced renal damage in diabetes. Regul. Pept. 2011, 166, 48-54. [CrossRef]

14. Makdissi, A.; Ghanim, H.; Vora, M.; Green, K.; Abuaysheh, S.; Chaudhuri, A.; Dhindsa, S. Paresh Dandona Sitagliptin exerts an antinflammatory action. J. Clin. Endocrinol. Metab. 2012, 97, 3333-3341. [CrossRef]

15. Gumieniczeka, A.; Berecka, A.; Mroczek, T.; Wojtanowski, K.; Dąbrowska, K.; Stẹpień, K. Determination of chemical stability of sitagliptin by LC-UV, LC-MS and FT-IR methods. Analysis 2019, 164, 789-807. [CrossRef]

16. Teodoro, J.S.; Nunes, S.; Rolo, A.P.; Reis, F.; Palmeira, C.M. Therapeutic options targeting oxidative stress, mitochondrial dysfunction and inflammation to hinder the progression of vascular complications of diabetes. Front. Physiol. 2018, 9, 1857. [CrossRef] [PubMed]

17. Sakura, H.; Hashimoto, N.; Sasamoto, K.; Ohashi, H.; Hasumi, S.; Ujihara, N.; Kasahara, T.; Tomonaga, O.; Nunome, H.; Honda, M.; et al. E_ect of sitagliptin on blood glucose control in patients with type 2 diabetes mellitus who are treatment naive or poorly responsive to existing antidiabetic drugs: The JAMP study. BMC Endocr. Disord. 2016, 16, 70. [CrossRef]

18. Buse, J.B.; Bethel, M.A.; Green, J.B.; Stevens, S.R.; Lokhnygina, Y.; Aschner, P.; Grado, C.R.; Tankova, T.; Wainstein, J.; Josse, R.; et al. Pancreatic safety of sitagliptin in the TECOS study. Diabetes Care 2017, 40, 164-170. [CrossRef]

19. Vrang, N.; Jelsing, J.; Simonsen, L.; Jensen, A.E.; Thorup, I.; Soeborg, H.; Knudsen, L.B. The e_ects of 13 wk of liraglutide treatment on endocrine and exocrine pancreas in male and female ZDF rats: A quantitative and qualitative analysis revealing no evidence of drug-induced pancreatitis. AJP Endocrinol. Metab. 2012, 303, E253-E264. [CrossRef]

20. El-Megharbel, S.M.; Hamza, R.Z.; Gobouri, A.A.; Refat, M.S. Synthesis of new antidiabetic agent by complexity between vanadyl (II) sulfate and vitamin B1: Structural, characterization, anti-DNA damage, structural alterations and antioxidative damage studies. Appl. Organomet. Chem. 2019, 33, e4892. [CrossRef]

21. Furman, B.L. Streptozotocin-induced diabetic models in mice and rats. Curr. Protoc. Pharmacol. 2015, 70, 5-47. [CrossRef] [PubMed]

22. Shawky, L.M.; Morsi, A.A.; el Bana, E.; Hanafy, S.M. The Biological Impacts of Sitagliptin on the Pancreas of a Rat Model of Type 2 Diabetes Mellitus: Drug Interactions with Metformin. Biology 2020, 9, 6. [CrossRef]

23. Sedlak, J.; Lindsay, R.H. Estimation of total, protein-bound, and nonprotein sulfhydryl groups in tissue with Ellman's reagent. J. Anal. Biochem. 1968, 25, 192. [CrossRef]

24. Ohkawa, H.; Ohishi, N.; Yagi, K. Assay for lipid peroxides in animal tissues by thiobarbituric acid reaction. Anal. Biochem. 1979, 95, 351. [CrossRef]

25. Beers, J.R.; Sizer, I.W. A spectrophotometric method for measuring the breakdown of hydrogen peroxide by catalase. J. Biol. Chem. 1952, 195, 133. [CrossRef]

26. Refat, M.S. Complexes of uranyl (II), vanadyl (II) and zirconyl (II) with orotic acid "vitamin B13": Synthesis, spectroscopic, thermal studies and antibacterial activity. J. Mol. Struct. 2007, 842, 24-37. [CrossRef]

27. Lever, A.B.P. Inorganic Electronic Spectroscopy; Elsevier: Amsterdam, The Netherlands, 1968.

28. Lever, A.B.P.; Mantovani, E. Far-infrared and electronic spectra of some bis (ethylenediamine) and related complexes of copper (II) and the relevance of these data to tetragonal distortion and bond strengths. Inorg. Chem. 1971, 10, 817-826. [CrossRef]

29. Drago, R.S.; Meek, D.W.; Joosten, M.S.; Laroche, L. Spectrochemical studies of a series of amides as ligands with nickel (II) and chromium (III). Inorg. Chem. 1963, 2, 124. [CrossRef]

30. Nakamoto, K. Infrared and Raman Spectra of Inorganic and Coordination Compounds; Wiely: New York, NY, USA, 1978.

31. Vein, D.L.; Colthup, N.B.; Fateley, W.G.; Grasselli, J.G. The Handbook of Infrared and Raman Characteristic Frequencies of Organic Molecules; Academic Press: San Diego, CA, USA, 1991.

32. Silverstein, R.M.; Besslor, G.C.; Morrni, D.T.C. Spectrometric Identification of Organic Compounds, 4th ed.; Wiley: New York, NY, USA, 1981.

33. Cullity, B.D. Elements of X-ray Diffraction, 2nd ed.; Addision-Wesley Publishing Company: New York, NY, USA, 1978.

34. Nelson, M.; Bhandari, N.; Wener, J. Sitagliptin-induced pancreatitis-A longer road than expected.Clin. Case Rep. 2014, 2, 149-152.

35. Kelany, M.E.; Hakami, T.M.; Omar, A.H.; Abdallah, M.A. Combination of Sitagliptin and Insulin against Type 2 Diabetes Mellitus with Neuropathy in Rats: Neuroprotection and Role of Oxidative and Inflammation Stress. Pharmacology 2016, 98, 242-250. [CrossRef]

36. Yang, V.L. Zinc and insulin in pancreatic beta-cells. Endocrine 2014, 45, 178-189.

37. Rouse, R.; Xu, L.; Stewart, S.; Zhang, J. High fat diet and GLP-1 drugs induce pancreatic injury in mice. Toxicol. Appl. Pharmacol. 2014, 276, 104-114. [CrossRef] [PubMed]

38. Hamza, R.Z.; Al-Motaani, S.E.; Al-Talhi, T. Therapeutic and Ameliorative Effects of Active Compounds of Combretum Molle in the Treatment and Relief from Wounds in a Diabetes Mellitus Experimental Model. Coatings 2021, 11, 324. [CrossRef] 
39. Bao, W.; Morimoto, K.; Hasegawa, T.; Sasaki, N.; Yamashita, T.; Hirata, K.; Okita, Y.; Okada, K. Orally administered dipeptidyl peptidase-4 inhibitor (alogliptin) prevents abdominal aortic aneurysm formation through an antioxidant effect in rats. J. Vasc. Surg. 2014, 59, 1098-1108. [CrossRef]

40. Zhang, C.; Shao, M.; Yang, H.; Chen, L.; Yu, L.; Cong, W.; Tian, H.; Zhang, F.; Cheng, P.; Jin, L.; et al. Attenuation of Hyperlipidemia- and Diabetes-Induced Early-Stage Apoptosis and Late-Stage Renal Dysfunction via Administration of Fibroblast Growth Factor-21 Is Associated with Suppression of Renal Inflammation. PLoS ONE 2013, 8, e82275. [CrossRef]

41. Czech, M.P. Insulin action and resistance in obesity and type 2 diabetes. Nat. Med. 2017, 23, 804-814. [CrossRef] [PubMed]

42. Wortham, M.; Sander, M. Mechanisms of $\beta$-cell functional adaptation to changes in workload. Diabetes Obes. Metab. 2016, 18, 78-86. [CrossRef] [PubMed]

43. DeFronzo, R.A. Pathogenesis of type 2 diabetes mellitus. In Diabetes Epidemiology, Genetics, Pathogenesis, Diagnosis, Prevention, and Treatment; Bonora, E., DeFronzo, R.A., Eds.; Springer: Cham, Switzerland, 2018; pp. 181-253.

44. Skovsø, S. Modeling type 2 diabetes in rats using high fat diet and streptozotocin. J. Diabetes Investig. 2014, 5, 349-358. [CrossRef] [PubMed]

45. Al-Harbi, M.S.; Hamza, R.Z. Potential Ameliorative Effects of Selenium and Chromium Supplementation Against Toxicity and Oxidative Stress in Streptozotocin Diabetic Rats. Int. J. Pharm. 2016, 12, 483-495. [CrossRef]

46. Riley, D.P. Functional mimics of superoxide dismutase enzymes as therapeutic agents. Chem. Rev. 1999, 99, 2573-2588. [CrossRef]

47. Hamza, R.Z.; Diab, A.A. Testicular protective and antioxidant effects of selenium nanoparticles on Monosodium glutamateinduced testicular structure alterations in male mice. Toxicol. Rep. 2020, 7, 254-260. [CrossRef] [PubMed]

48. Al-Baqami, N.M.; Hamza, R.Z. Protective Effect of Resveratrol against Hepatotoxicity of Cadmium in Male Rats: Antioxidant and Histopathological Approaches. Coatings 2021, 11, 594. [CrossRef]

49. Kramer, R. The Pharmaceutical Potential of Manganese-Based Superoxide Dismutase Mimics. Angew Chem. Int. Ed. 2000, 39, 4469-4470. [CrossRef]

50. Zhu, M.; Zhou, J.; Jin, Y.; Gao, L.; Li, L.; Yang, J.; Lu, C.; Zhao, Q.H.; Xie, M. A manganese-salen complex as dipeptidyl peptidase IV inhibitor for the treatment of type 2 diabetes. Int. J. Biol. Macromol. 2018, 120, 1232-1239. [CrossRef]

51. Kuhad, A.; Chopra, K. Tocotrienol attenuates oxidative-nitrosative stress and inflammatory cascade in experimental model of diabetic neuropathy. Neuropharmacology 2009, 57, 456-462. [CrossRef]

52. Hocher, B.; Reichetzeder, C.; Alter, M.L. Renal and cardiac effects of DPP4 inhibitors—From preclinical development to clinical research. Kidney Blood Press Res. 2012, 36, 65-84. [CrossRef]

53. Salcedo, I.; Tweedie, D.; Li, Y.; Greig, N.H. Neuroprotective and neurotrophic actions of glucagon- like peptide-1: An emerging opportunity to treat neurodegenerative and cerebrovascular disorders. Br. J. Pharmacol. 2012, 166, 1586-1599. [CrossRef] [PubMed]

54. Shakeel, M. Recent advances in understanding the role of oxidative stress in diabetic neuropathy. Diabetes Metab. Syndr. 2015, 9 , 373-378. [CrossRef]

55. Al-Baqami, N.M.; Hamza, R.Z. Synergistic antioxidant capacities of vanillin and chitosan nanoparticles against reactive oxygen species, hepatotoxicity, and genotoxicity induced by aging in male Wistar rats. Hum. Exp. Toxicol. 2021, 40, 183-202. [CrossRef] [PubMed]

56. Pittas, A.G.; Dawson-Hughes, B.; Li, T.; van Dam, R.M.; Willett, W.C.; Manson, J.E.; Hu, F.B. Vitamin D and Calcium Intake in Relation to Type 2 Diabetes in Women. Diabetes Care 2006, 29, 650-656. [CrossRef] [PubMed]

57. Brown, R.O.; Forloines-Lynn, S.; Cross, R.E.; Heizer, W.D. Chromium deficiency after long-term total parenteral nutrition. Dig. Dis. Sci. 1986, 31, 661-664. [CrossRef] [PubMed]

58. Ahmed, Z.A.; Abtar, A.N.; Othman, H.H.; Aziz, T.A. Effects of quercetin, sitagliptin alone or in combination in testicular toxicity induced by doxorubicin in rats. Drug Des. Dev. Ther. 2019, 13, 3321. [CrossRef] [PubMed] 